\title{
Characterizing effects of monsoons and climate teleconnections on precipitation in China using wavelet coherence and global coherence
}

\author{
Xueyu Chang ${ }^{1} \cdot$ Binbin Wang $^{2} \cdot$ Yan Yan $^{1} \cdot$ Yonghong Hao $^{3}$ (D) Ming Zhang ${ }^{4}$
}

Received: 21 December 2017 / Accepted: 9 September 2018 / Published online: 14 September 2018

(c) The Author(s) 2018

\begin{abstract}
Weather and climate in a location are generally affected by global climatic phenomena. Monsoons and teleconnections are two climatic phenomena that have been assessed in specific regions for their correlations with regional precipitation. This study characterized the effects of monsoons and climate teleconnections on precipitation in eight climate zones across China. Correlations between monthly precipitation from 1951 to 2013 across the eight zones and each of two important monsoon indices [the Indian Summer Monsoon (ISM) and East Asian Summer Monsoon (EASM)] and two major teleconnection indices [El Niño-Southern Oscillation (ENSO) and Pacific Decadal Oscillation (PDO)] were analyzed based on wavelet coherence and global coherence. The results demonstrated that on the annual timescale, monsoons have stronger effects than teleconnections on monthly precipitation in each of the eight climate zones. On the intra-annual (0.5-1 year) and inter-annual (2-10 year) scales, the ISM mainly affects precipitation in the East Arid Region, Northeastern China, Northern China, and Qinghai-Tibet Plateau; the EASM mainly affects Northern China, Central China, and Southern China; the ENSO mainly affects Western Arid/Semiarid region and Qinghai-Tibet Plateau; the PDO mainly affects the Western Arid/Semiarid region. On the decadal timescale, the ISM mainly affects the Western arid/Semiarid and Central China; the EASM mainly affects Western arid/Semiarid, Central China, and Qinghai-Tibet Plateau; the ENSO mainly affects Northeastern China and Central China; and the PDO mainly affects East arid and Southern China regions. These findings provide a practical reference for water resources management and/or for the prediction of precipitation in different regions of China.
\end{abstract}

Keywords Precipitation · Spatiotemporal distribution · Indian Summer Monsoon · East Asia Summer Monsoon · El NiñoSouthern Oscillation · Pacific Decadal Oscillation

Yonghong Hao

haoyh@sxu.edu.cn; haoyhong@yahoo.com

1 College of Geography and Environment, Tianjin Normal University, Tianjin 300387, China

2 Department of Civil and Environmental Engineering, University of Missouri, Columbia, MO 65211, USA

3 Tianjin Key Laboratory of Water Resources and Environment, Tianjin Normal University, Tianjin 300387, China

4 Geological Survey of Japan, National Institute of Advanced Industrial Science and Technology (AIST), Tsukuba, Ibaraki 305-8567, Japan

\section{Introduction}

Monsoons and teleconnections are two important large-scale climatic phenomena that affect global precipitation and distribution of the global water resources (Christensen et al. 2013). Since the 1990s, hydrologists have paid increasing attention to the study of the relationships between these large-scale climatic factors and both surface runoff (Peng and Mysak 1993; Chiew et al. 1998; Gadgil and Sajani 1998) and groundwater level (Winograd et al. 1998; Fleming and Quilty 2006; Tremblay et al. 2011). It is well known that many large-scale climatic factors (represented by different climate indices) have strong heterogeneity at both spatial and temporal scales (Karl et al. 1999; Sun et al. 2017). Hence, understanding their characteristic scales in both space and time is crucially important to the allocation and management of local water resources. 
Monsoons and teleconnections can be represented by several indices (Webster et al. 1998; Trenberth et al. 2000; Xu et al. 2015; Xiao et al. 2015). Previous works have indicated that the Indian Summer Monsoon (ISM) and East Asian Summer Monsoon (EASM) are two major monsoon indices that affect Asian precipitation (Lau and Li 1984; Wang et al. 2001). In addition, the El Niño-Southern Oscillation (ENSO) and Pacific Decadal Oscillation (PDO) are two important teleconnection indices that also impact Asian precipitation (Hamada et al. 2002; Chan and Zhou 2005; Zhou and Wu 2010; Xiao et al. 2015). To date, the ISM, EASM, ENSO, and PDO are considered to be primary climatic indices that contribute greatly to regional precipitation in China. Most previous studies have focused on specific regions, and an integrated and systematic assessment of the effects of monsoons and teleconnections on precipitation across China remains lacking. In particular, the timescales over which these climatic indices affect different regions of China remain unclear. In this study, we applied wavelet analysis to quantitatively evaluate the effects of four major indices (ISM, EASM, ENSO, and PDO) on precipitation within China, using precipitation data recorded during 1951-2013 at 756 meteorological stations nationwide.
Detailed assessment was performed over eight climate zones with varying climate patterns. The effects of each climate index were evaluated on each climate zone to illustrate the characteristics of their spatiotemporal correlations with precipitation.

\section{Data and analytical methods}

\subsection{Data}

China is a large country covering an area of about 9.6 million $\mathrm{km}^{2}$. Although China is generally divided into six zones (such as on ClimateList) based on temperature, it is also divided into eight climatic zones based on both precipitation and climate regionalization (Zhang and Lin 1985; Xiao et al. 2013). In this work, we focus on the analysis of precipitation data and climate indices, thus, adopt the latter classification (Fig. 1): Zone I (Western arid/Semiarid), Zone II (East arid), Zone III (Northeastern China), Zone IV (Northern China), Zone V (Central China), Zone VI (Southern China), Zone VII (Southwestern China), and Zone VIII (Qinghai-Tibet Plateau). The geographical characteristics and locations

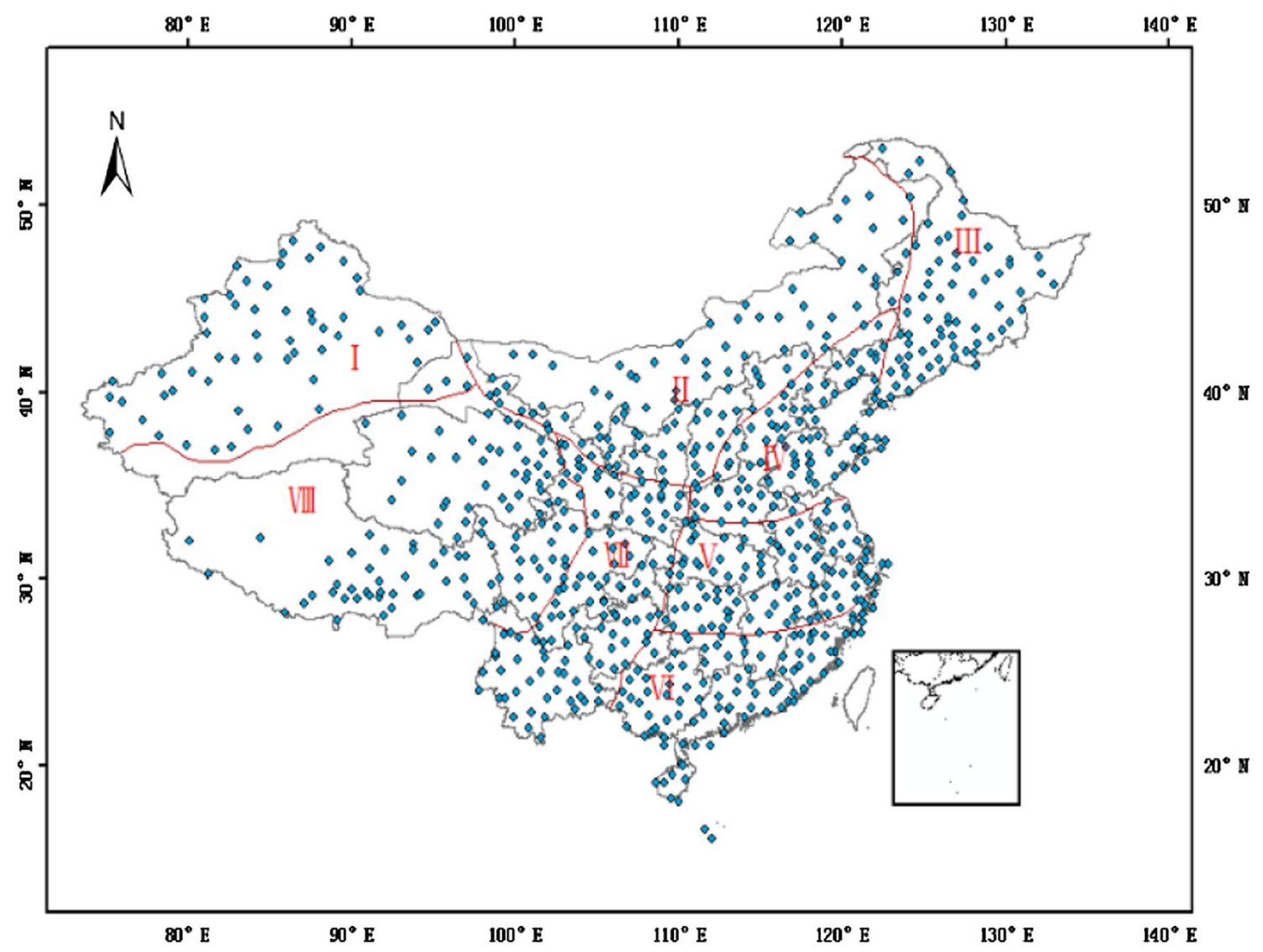

Fig. 1 The climate zones in China and locations of meteorological stations across China (after Zhang and Lin 1985; Xiao et al. 2013) 
of the individual climate zones, as well as the numbers of meteorological stations within each climate zone, are summarized in Table 1.

Monthly precipitation data recorded during 1951-2013 at the 756 meteorological stations distributed across China were used for the analysis. These data were obtained from the China Meteorological Data Service Center (http://data. cma.cn/en/). The monthly precipitation data from all stations within each climate zone were averaged to represent the regional monthly precipitation (Fig. 2). Monthly means of the ISM were obtained from the Monsoon Monitoring Page maintained by the University of Hawaii (http://apdrc .soest.hawaii.edu/projects/monsoon/). Monthly means of the EASM were collected from the National Oceanic and Atmospheric Administration (http://www.cpc.ncep.noaa. gov/products/Global_Monsoons/Asian_Monsoons/monso on_index.shtml/). ENSO values were derived from the sea surface temperature in the Niño3.4 region $\left(5^{\circ} \mathrm{N}-5^{\circ} \mathrm{S}\right.$, $120^{\circ}-170^{\circ} \mathrm{W}$ ), and the Niño3.4 indices were extracted from the Climate Prediction Center of NOAA (http://origin.cpc. ncep.noaa.gov/products/analysis_monitoring/ensostuff/detre nd.nino34.ascii.txt). The PDO index was obtained from the Earth System Research Laboratory of NOAA (http://www. esrl.noaa.gov/psd/data/correlation/pdo.data/).

\subsection{Analytical methods}

Wavelet coherence and global coherence were used to characterize the relationships between regional monthly precipitation and the four selected climate indices: the ISM, EASM, ENSO, and PDO.

\subsubsection{Wavelet coherence}

Wavelet coherence is an approach used for analyzing the degree of coherence of cross wavelet transform in time-frequency space. Following Torrence and Webster (1999), the wavelet coherence coefficient can be defined as follows (Grinsted et al. 2004; Hao et al. 2016):

$$
R^{2}(a, \tau)=\frac{\left|S\left(a^{-1} W_{x y}(a, \tau)\right)\right|^{2}}{S\left(a^{-1}\left|W_{x}(a, \tau)\right|^{2}\right) \cdot S\left(a^{-1}\left|W_{y}(a, \tau)\right|^{2}\right)}
$$

where $R^{2}(\alpha, \tau)$ takes values between 0 (no coherency) and 1 (perfect coherency), $\alpha$ is the scale expansion parameter, $\tau$ is the dimensionless time-shift parameter, $W_{x y}(\alpha, \tau)$ is the cross wavelet transform of the two time series, $W_{\mathrm{x}}$ and $W_{\mathrm{y}}$ are the sums of ranks of observations in samples $x_{t}$ and $y_{t}$, respectively, and $S$ represents a smoothing operator, which is defined as:

$S(W)=S_{\text {scale }}\left(S_{\text {time }}(W(\alpha, \tau))\right)$

where $S_{\text {scale }}$ and $S_{\text {time }}$ represent smoothing along the wavelet scale axis and in time, respectively.

The definition of Eq. (1) is similar to that of a traditional correlation coefficient, and it allows consideration of wavelet coherence as a localized correlation coefficient in time-frequency space. Referring to Torrence and Compo (1998), a suitable smoothing operator for the Morlet wavelet can be determined with the following equation:

$$
\begin{aligned}
\left.S_{\text {time }}(W)\right|_{\alpha} & =\left.\left(W(\alpha, \tau) \cdot c_{1}^{\frac{-t^{2}}{2 \alpha^{2}}}\right)\right|_{\alpha}, \\
\left.S_{\text {time }}(W)\right|_{\tau} & =\left.\left(W(\alpha, \tau) \cdot c_{2} \Pi(0.6 \alpha)\right)\right|_{\tau}
\end{aligned}
$$

where $c_{1}$ and $c_{2}$ are normalization constants and $\pi$ is the rectangle function. The factor of 0.6 is an empirically deter-

\begin{tabular}{|c|c|c|c|}
\hline Climate zone & Characteristics & Provinces and regions & $\begin{array}{l}\text { Number of meteorolog- } \\
\text { ical stations (total: } 756 \text { ) }\end{array}$ \\
\hline Zone I & Western arid/Semiarid & Most of Xinjiang, northwestern Gansu & 59 \\
\hline Zone II & East arid & $\begin{array}{l}\text { Inner Mongolia, eastern Gansu, Ningxia, northern Shaanxi, most of Shanxi, } \\
\text { northwestern Hebei }\end{array}$ & 101 \\
\hline Zone III & Northeastern China & Heilongjiang, Jilin, eastern Liaoning & 75 \\
\hline Zone IV & Northern China & $\begin{array}{l}\text { Southeastern Heibei, Shandong, small parts of southeastern Shanxi, most of } \\
\text { Henan }\end{array}$ & 88 \\
\hline Zone V & Central China & Middle-lower Yangtze Plain & 98 \\
\hline Zone VI & Southern China & $\begin{array}{l}\text { Most of Fujian, southern Hunan, Jiangxi, small parts of southeastern Guizhou, } \\
\text { Guangzhou, Guangxi, Hainan }\end{array}$ & 109 \\
\hline Zone VII & Southwestern China & $\begin{array}{l}\text { Northern Gansu, Shaanxi, eastern Yunnan, most of Sichuan, Guizhou, Chong- } \\
\text { qing }\end{array}$ & 114 \\
\hline Zone VIII & Qinghai-Tibet Plateau & Tibet, Qinghai, western Yunnan & 112 \\
\hline
\end{tabular}
mined scale decorrelation length for the Morlet wavelet

Table 1 Geographical characteristics and locations of the eight climate zones in China 
(a)

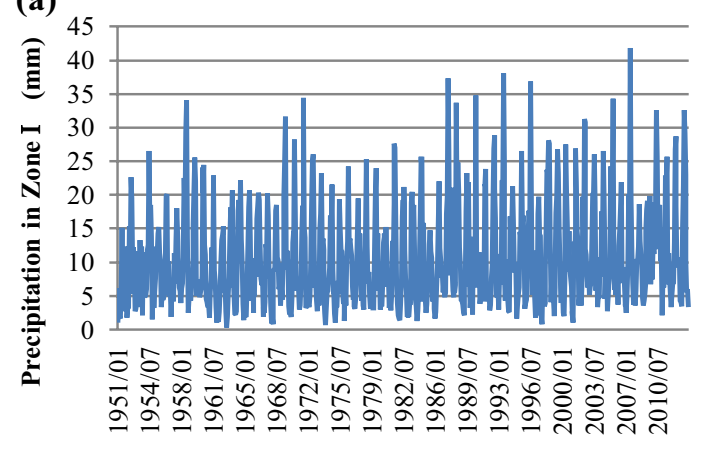

Time (month)

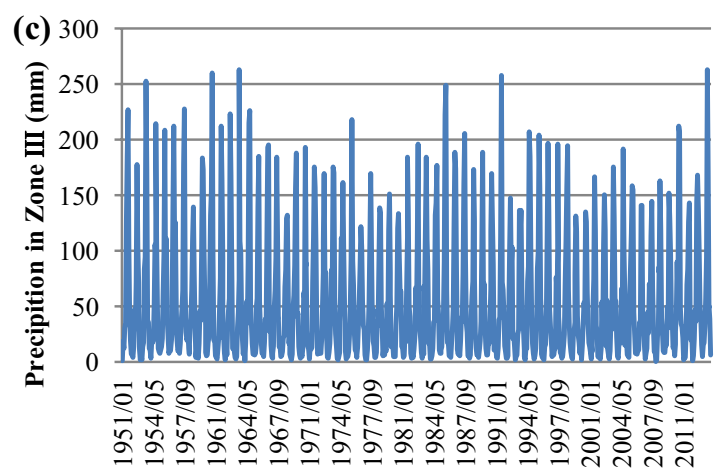

Time (month)
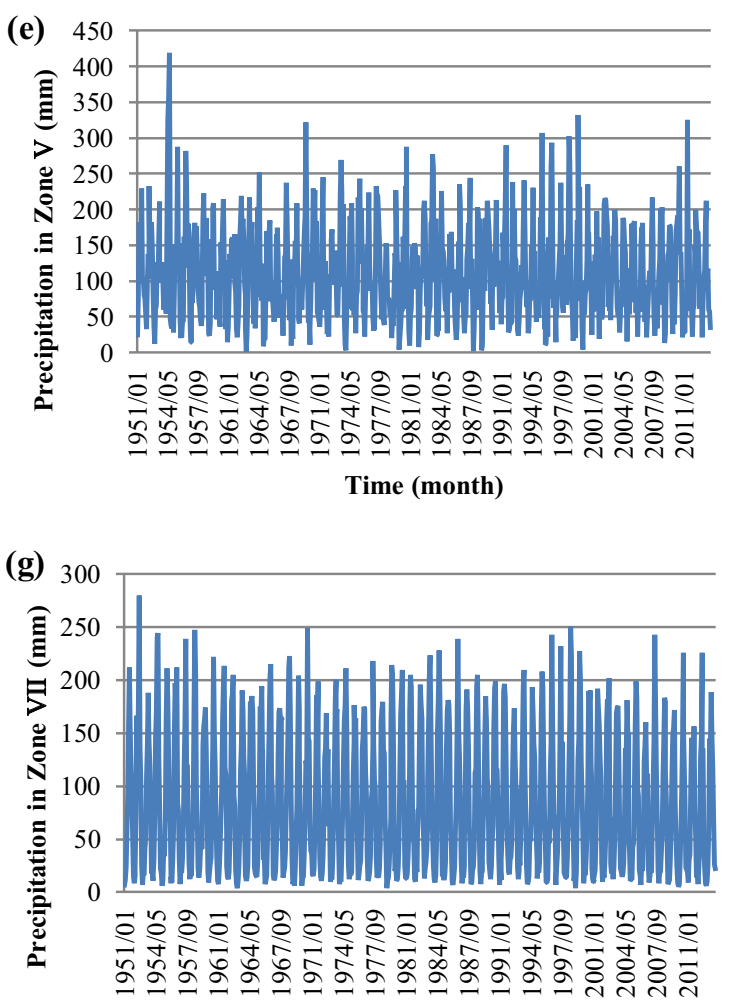

Time (month)
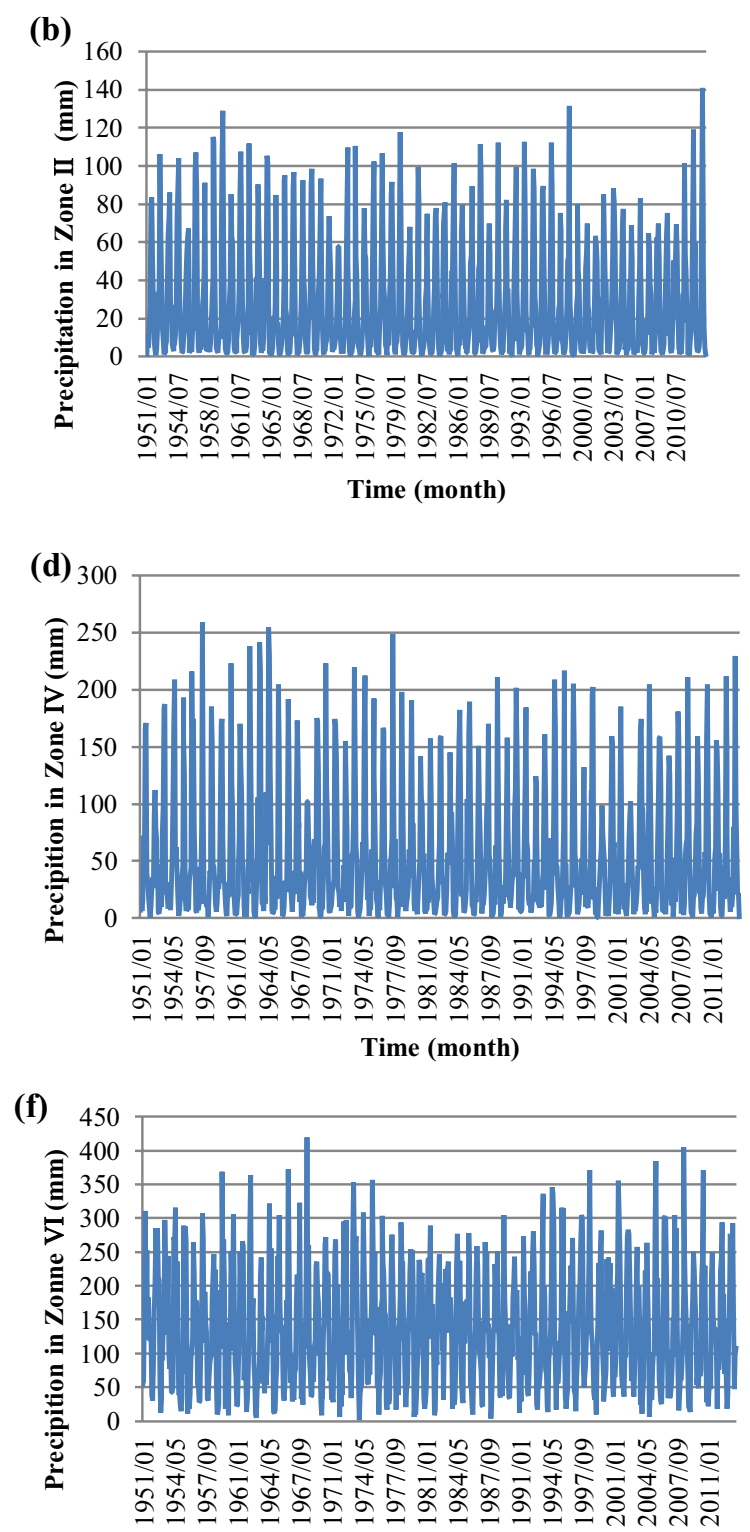

Time (month)

(h)

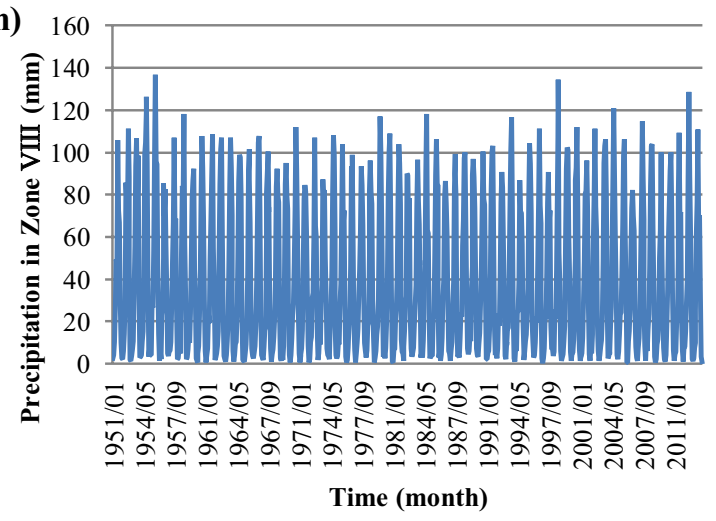

Fig. 2 The monthly precipitation in the eight zones 
(Torrence and Compo 1998). In practice, both convolutions are processed discretely and thus the two normalization constants are numerically determined.

The statistical significance level of wavelet coherence was estimated through Monte Carlo simulations, which require more than 1000 surrogate dataset pairs with the same first order autoregressive coefficients as the input datasets. The significance level for each scale was estimated using only the values outside the Cone of Influence, which is the region of the wavelet spectrum in which edge effects become important (Torrence and Compo 1998). The number of scales per octave should be sufficiently high to capture the rectangle shape of the scale smoothing operator while minimizing computing time. An empirically satisfactory parameter, i.e., 12 scales per octave, was used with reference to Torrence and Compo (1998). In addition, periodicities different from noise that were significant at the $5 \%$ level, i.e., coherence for which the confidence level was $>95 \%$, were analyzed in this study.

\subsubsection{Global coherence}

With reference to Partal and Kucuk (2006), the global wavelet coherence coefficient at scale $\alpha$ can be defined as timeaveraged wavelet coherence coefficients:

$\bar{R}^{2}(\alpha)=\frac{1}{n} \sum_{\tau=1}^{n} R^{2}(\alpha, \tau)$

where $n$ is the number of points in the time scale.

The global coherence coefficient can be used to evaluate the correlation between two time-series at different scales while neglecting the influence of time. This parameter is useful for examining the characteristic of periodicities (Torrence and Compo 1998; Labat 2010). A cross wavelet and wavelet coherence toolbox for MATLAB, downloaded from http://grinsted.github.io/wavelet-coherence/, was used for this analysis (Grinsted et al. 2004).

\section{Results}

\subsection{Wavelet coherence}

\subsubsection{Wavelet coherence between monthly precipitation and the ISM}

Figure 3 shows the wavelet coherence between monthly precipitation and the ISM in the eight climate zones with phase lags between components as illustrated by black arrows (the same hereafter). High wavelet coherence (larger than 0.8) is observed at the annual scale, indicating the dominant effect of the ISM on precipitation across entire area of China on the annual timescale. In addition, relatively high wavelet coherence (0.6-0.8) is observed for the periodicity of intraannual (i.e., 0.5-1.0 year) and inter-annual scales (i.e., $>2.0$ but $<10.0$ years) in different climate zones and in different years. For example, the effects of the ISM are important in Zones I, II, III, IV, VI, and VIII on timescales of between 0.5 and 1.0 year (Fig. 3a-d, g, h). However, the effects of the ISM on the inter-annual timescale are intermittent, as demonstrated by the different sizes of the patches of high coherence in different years. Moreover, the effects of the ISM on the decadal timescale (i.e., $>10.0$ years) are also important in a few zones, particularly Zones I and V.

\subsubsection{Wavelet coherence between monthly precipitation and the EASM}

Figure 4 shows the wavelet coherence between monthly precipitation and the EASM in the eight climate zones. Similar to the effects of the ISM, strong and continuous wavelet coherence is observed for the periodicity of 1.0 year in all eight climate zones. However, the effects of the EASM on the intra-annual timescale (i.e., 0.5-1.0 year) are weaker than the ISM in most zones. The effects of the EASM on the inter-annual timescale are also intermittent in all eight zones. On the decadal timescale, the effects of the EASM are observed in most zones but the strength of the coherence varies considerably. The strength of the coherence is significantly different interannually, indicating strong spatiotemporal variability.

\subsubsection{Wavelet coherence between monthly precipitation and the ENSO}

Figure 5 shows the wavelet coherence between monthly precipitation and the ENSO in the eight climate zones. The influence of the ENSO is very different from that of the monsoon indices (i.e. ISM and EASM). No strong and continuous effect is evident for the periodicity of 1.0 year. Statistically, annual-scale coherence has no significant difference from the coherence on timescales of $<1.0$ year. The intermittency of other scales is also evident in all climate zones, although high coherence is observed on different timescales in different zones and during different years. For instance, the data shows that the inter-annual scale coherence (e.g., 2.0-8.0 years) is high in Zones I, II, V, and VIII (Fig. 5a, b, e, h), while the decadal-scale coherence (e.g., 10.0-16.0 years) is high in Zones III and V (Fig. 5c, e).

\subsubsection{Wavelet coherence between monthly precipitation and the PDO}

Figure 6 shows the wavelet coherence between monthly precipitation and the PDO in the eight climate zones. Similar to the ENSO, there is no evident continuous coherence between 
(a)

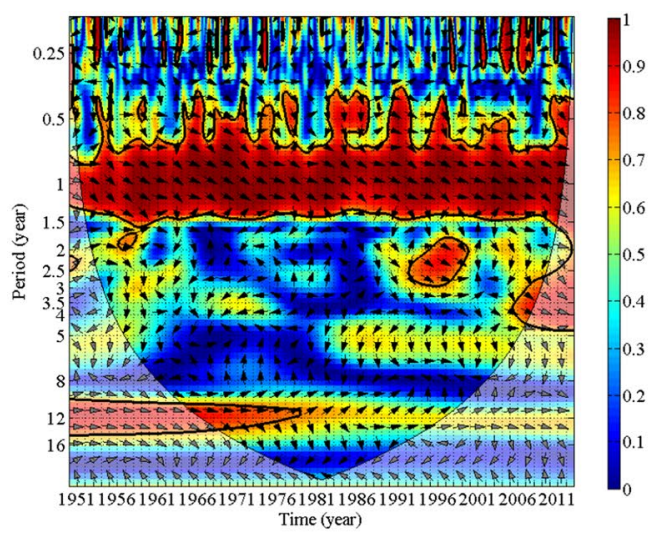

(c)

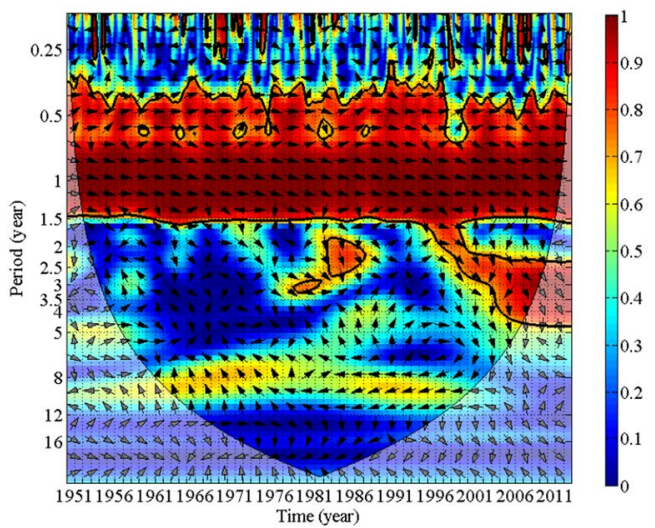

(e)

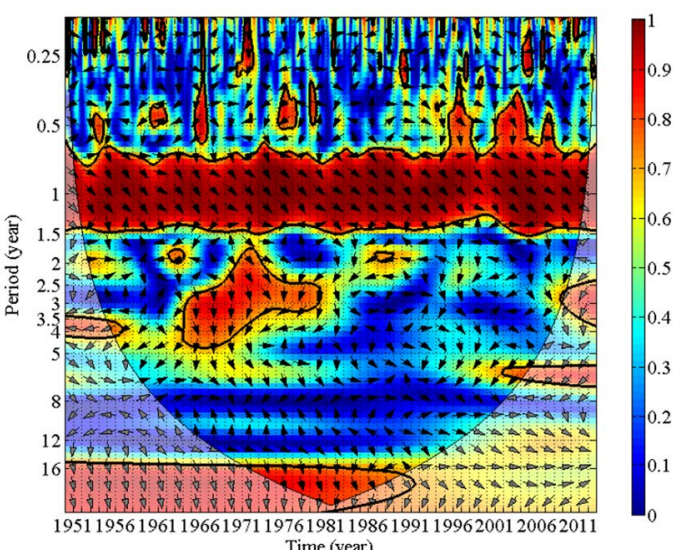

(g)

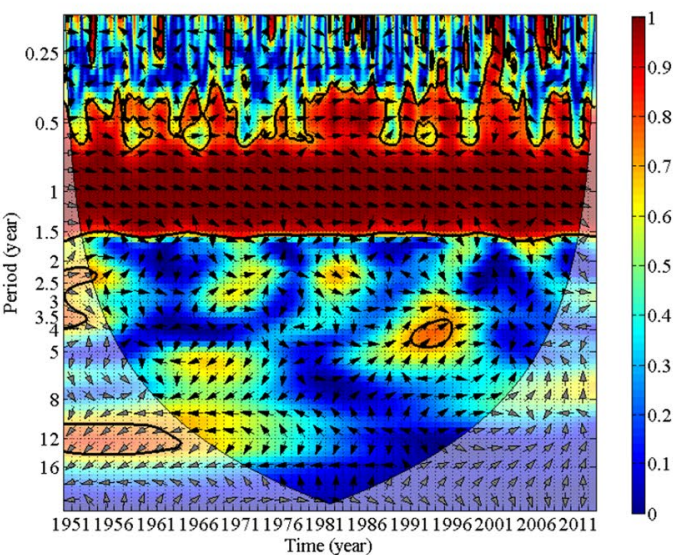

(b)

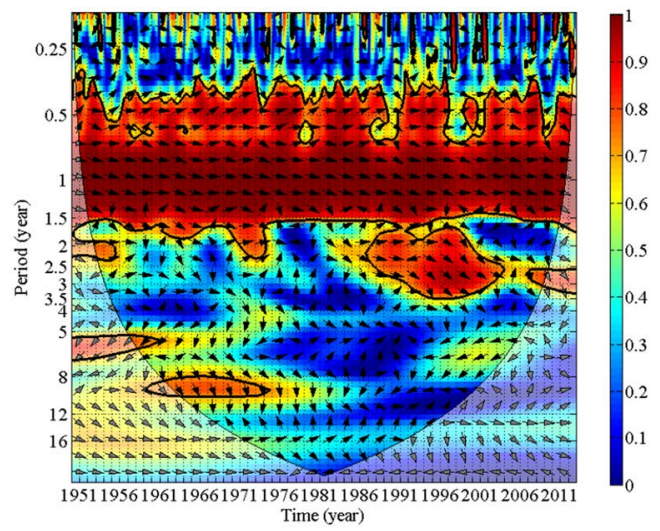

(d)

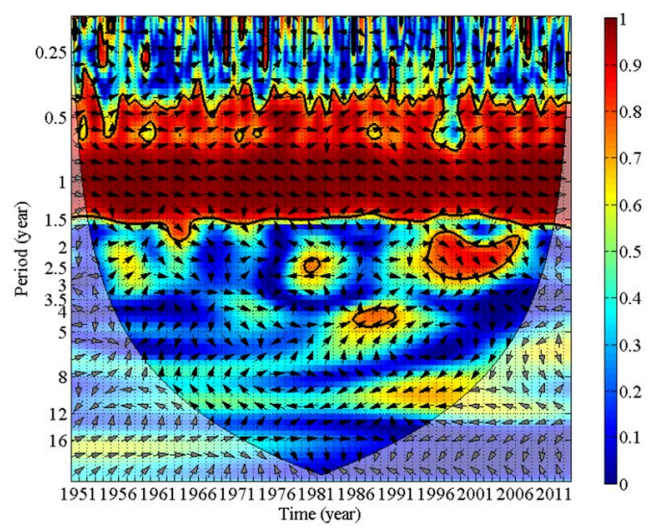

(f)

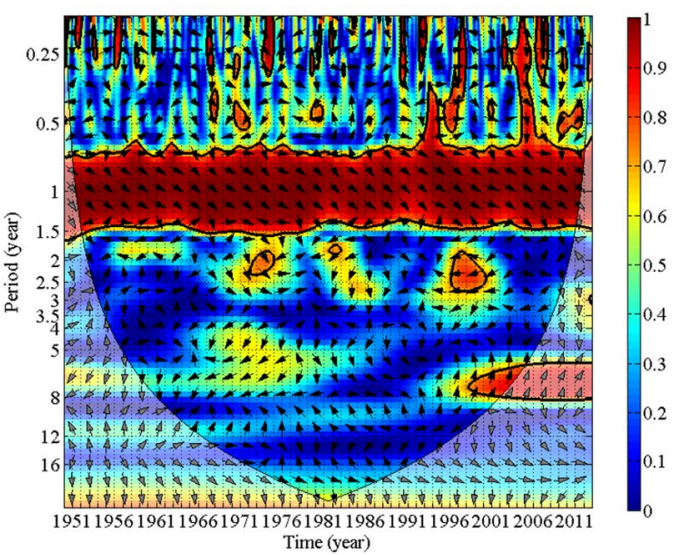

(h)

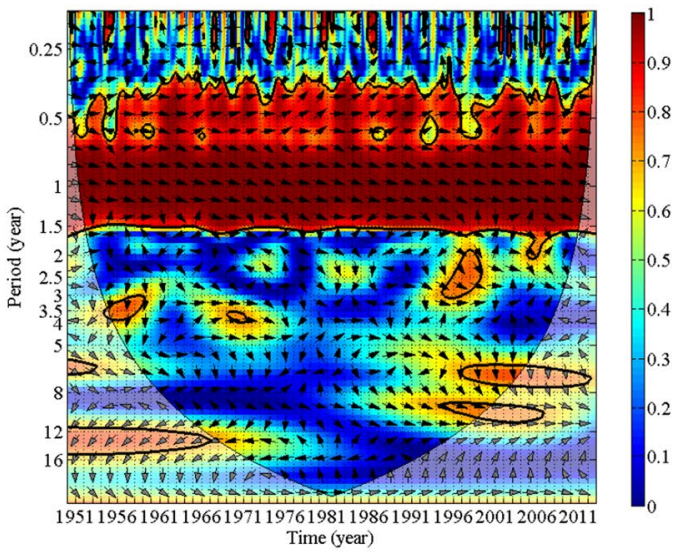

Fig. 3 Wavelet coherence between monthly precipitation and the ISM: a zone I, b zone II, $\mathbf{c}$ zone III, $\mathbf{d}$ zone IV, e zone V, $\mathbf{f}$ zone VI, $\mathbf{g}$ zone VII, and $\mathbf{h}$ zone VIII 
(a)

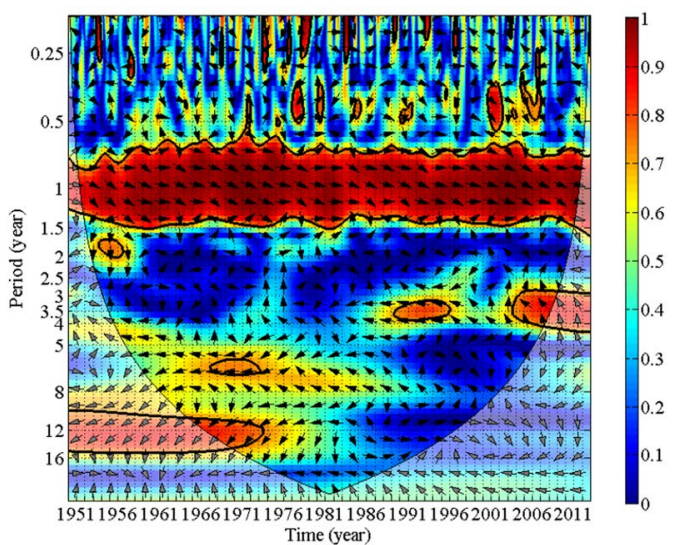

(c)

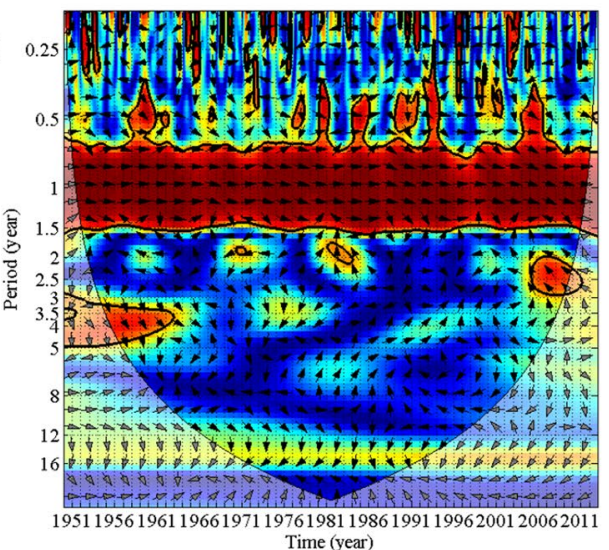

(e)

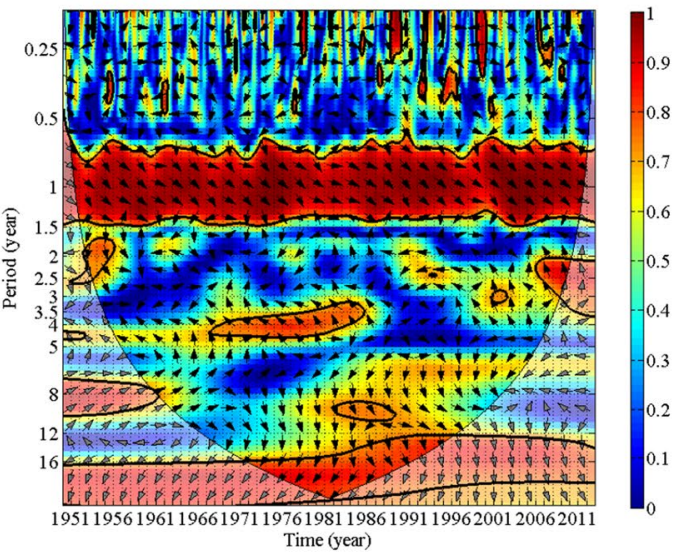

(g)

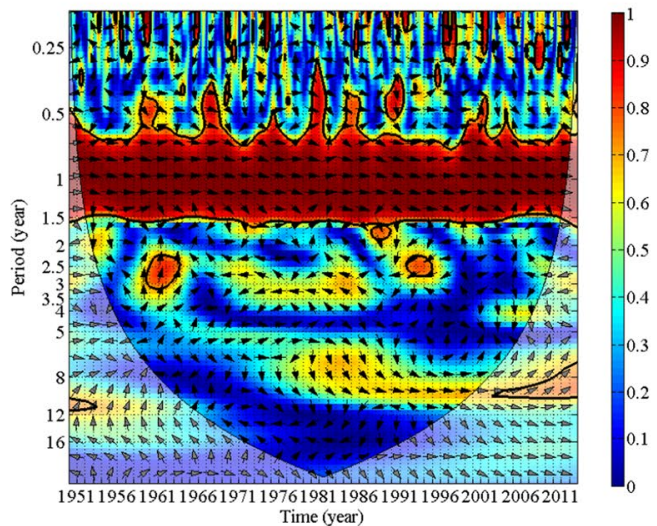

(b)

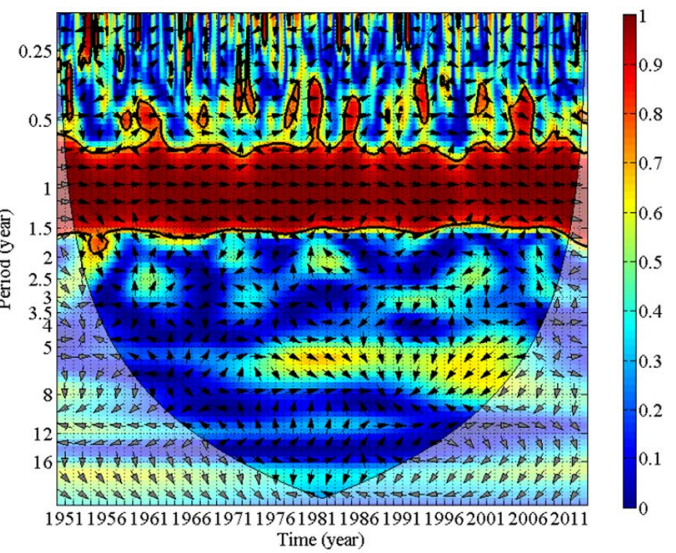

(d)

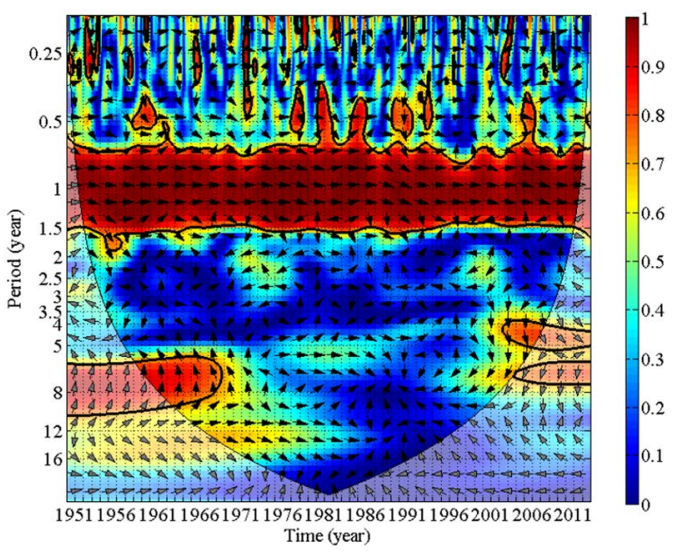

(f)

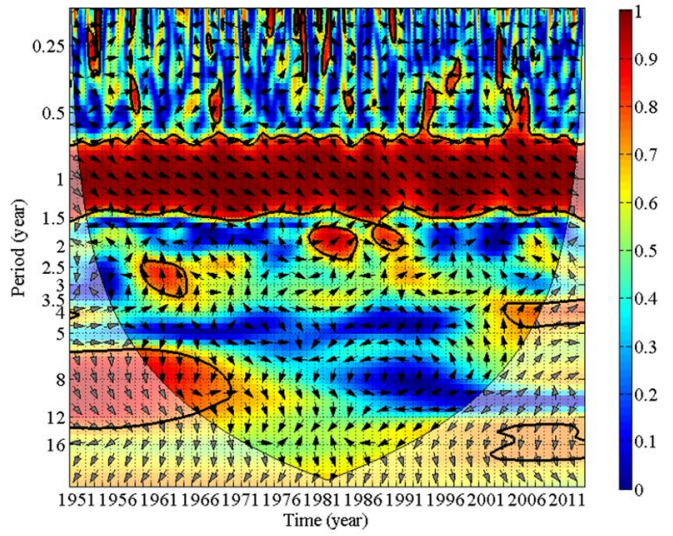

(h)

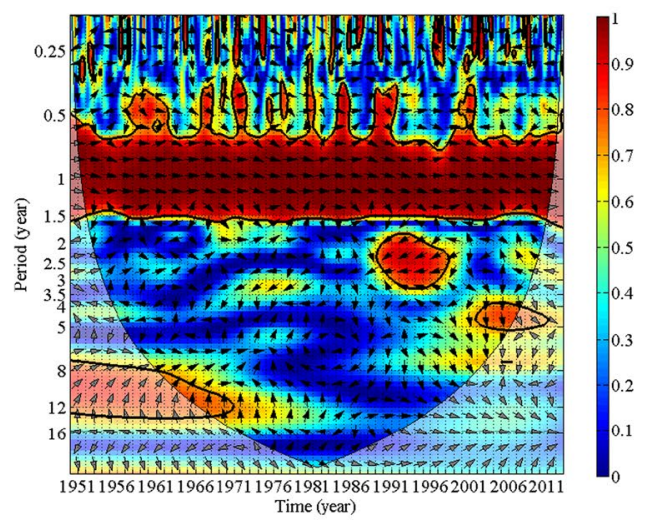

Fig. 4 Wavelet coherence between monthly precipitation and the EASM: a zone I, $\mathbf{b}$ zone II, $\mathbf{c}$ zone III, $\mathbf{d}$ zone IV, e zone V, $\mathbf{f}$ zone VI, $\mathbf{g}$ zone VII, and $\mathbf{h}$ zone VIII 
(a)

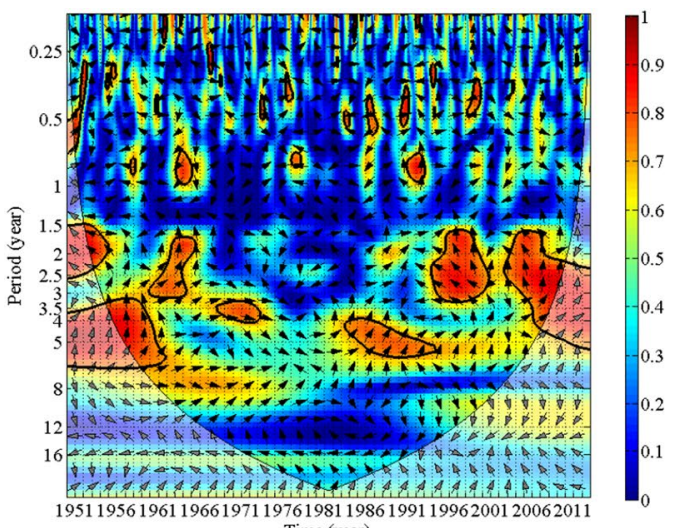

(c)

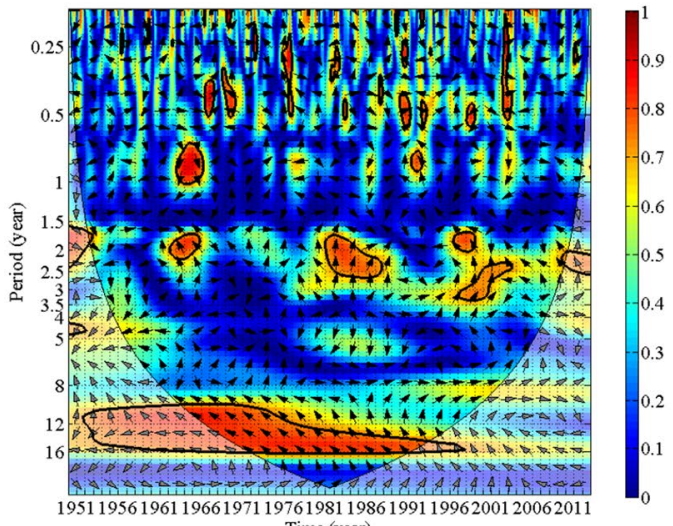

(e)

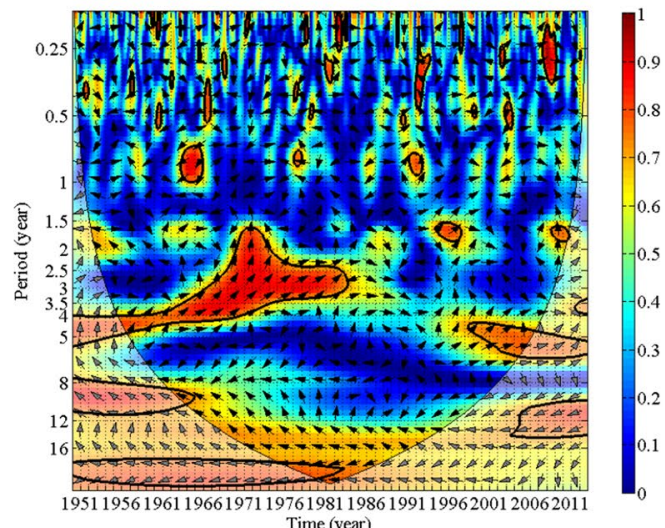

(g)

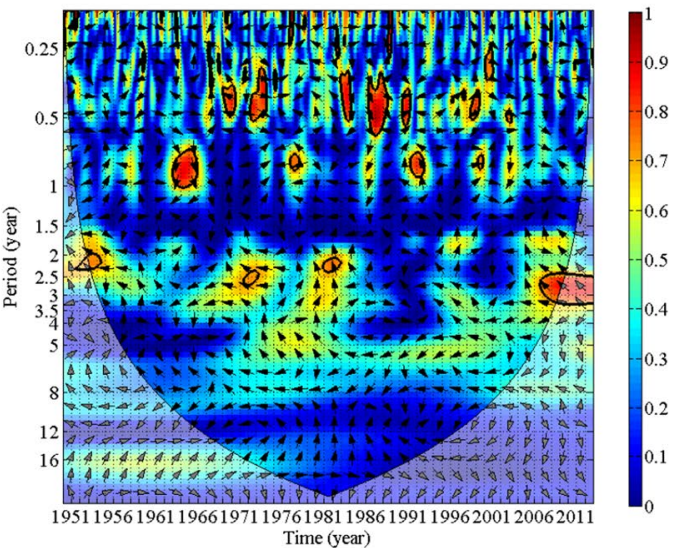

(b)

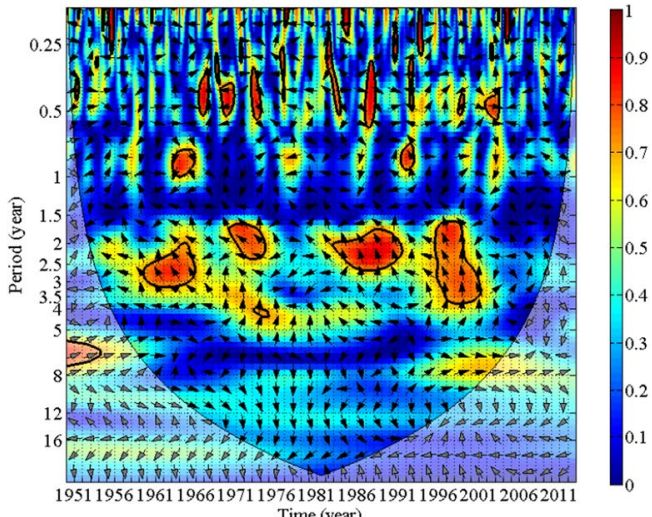

(d)

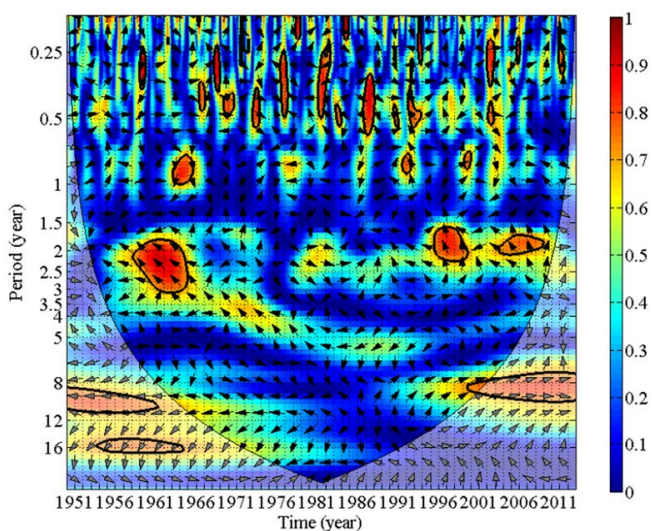

(f)

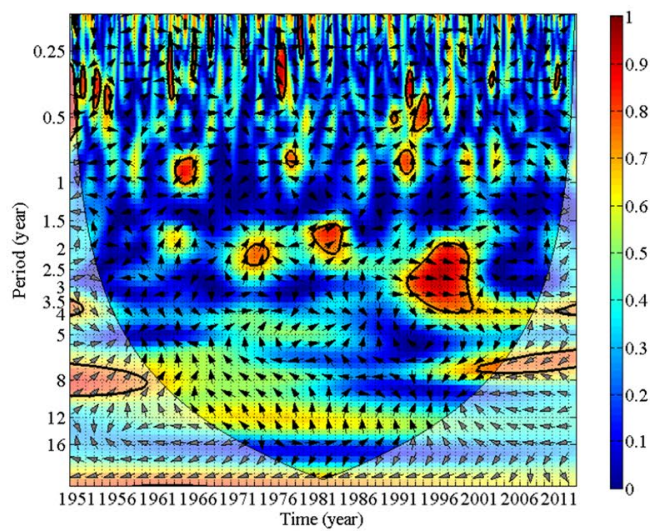

(h)

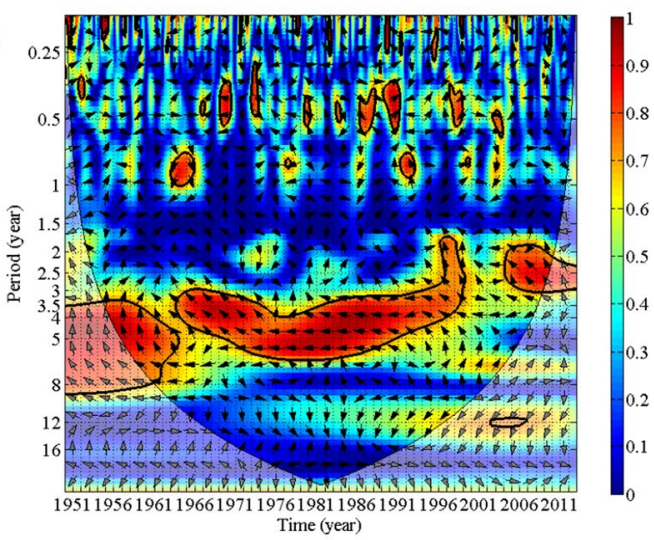

Fig. 5 Wavelet coherence between monthly precipitation and the ENSO: a zone I, b zone II, $\mathbf{c}$ zone III, $\mathbf{d}$ zone IV, e zone V, f zone VI, $\mathbf{g}$ zone VII, and $\mathbf{h}$ zone VIII 
(a)

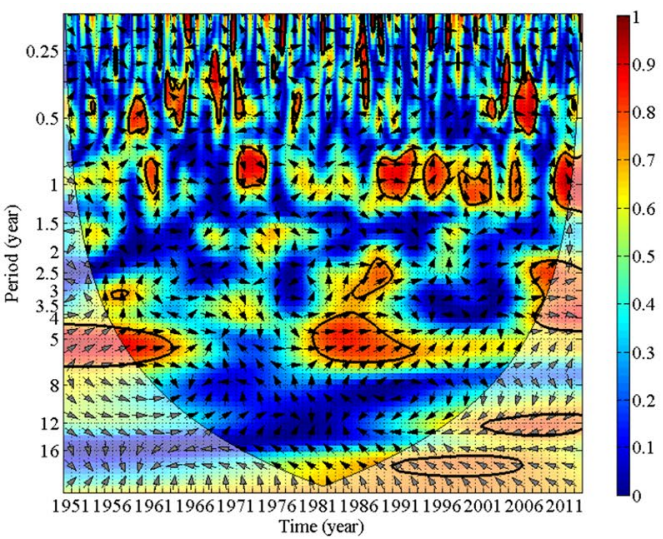

(c)

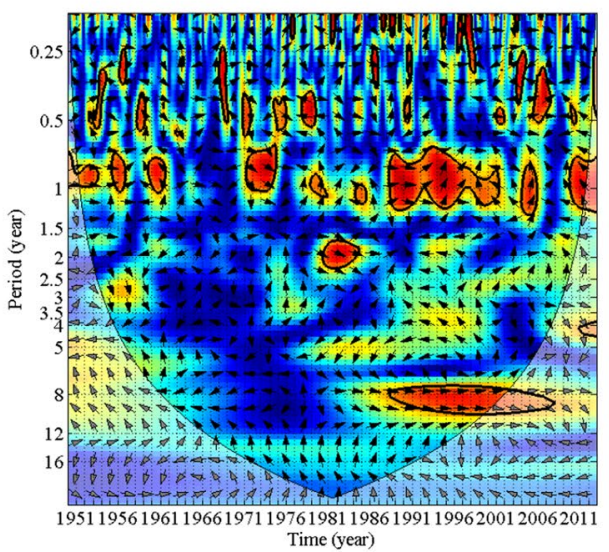

(e)

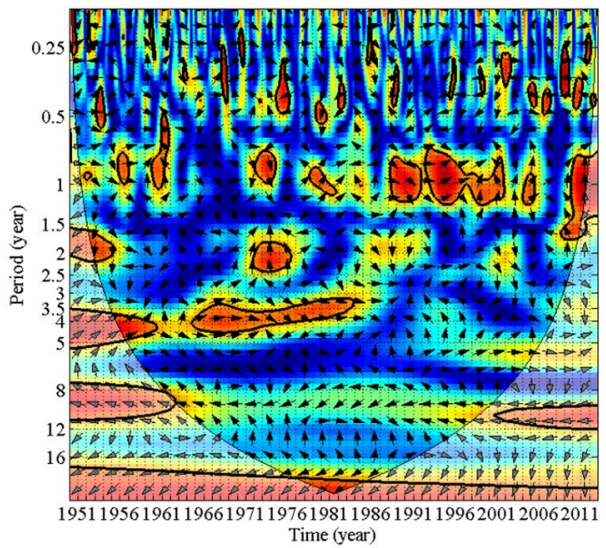

(g)

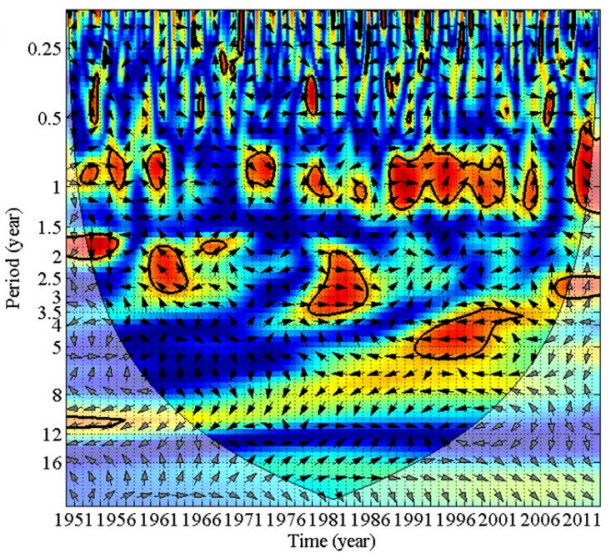

(b)

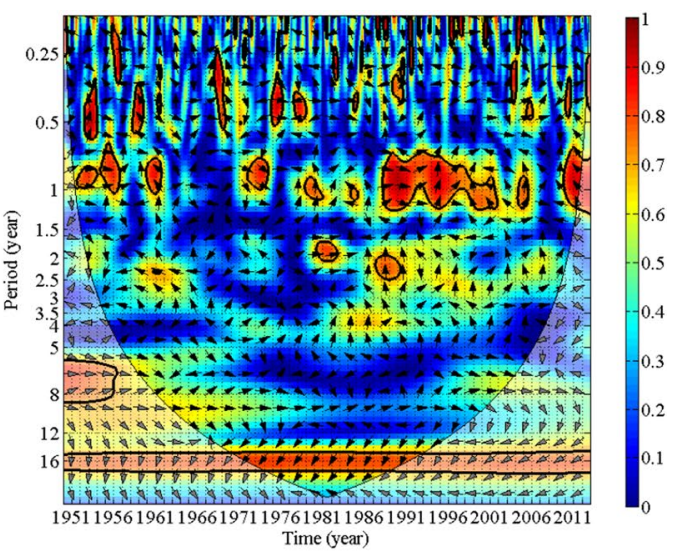

(d)

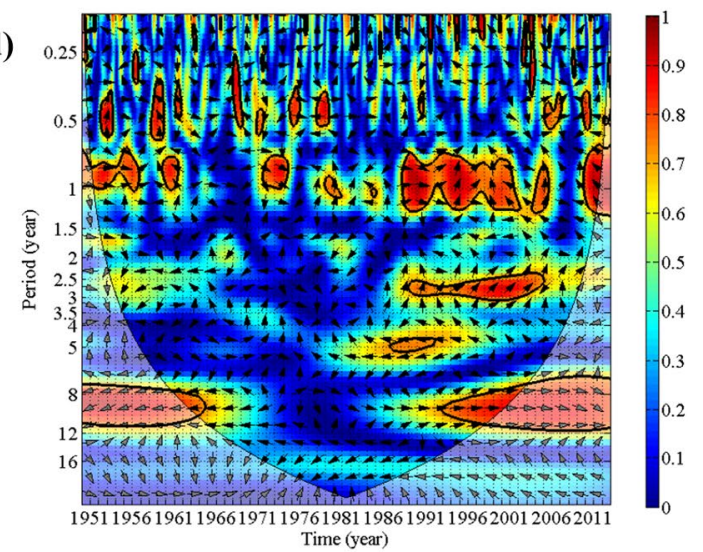

(f)

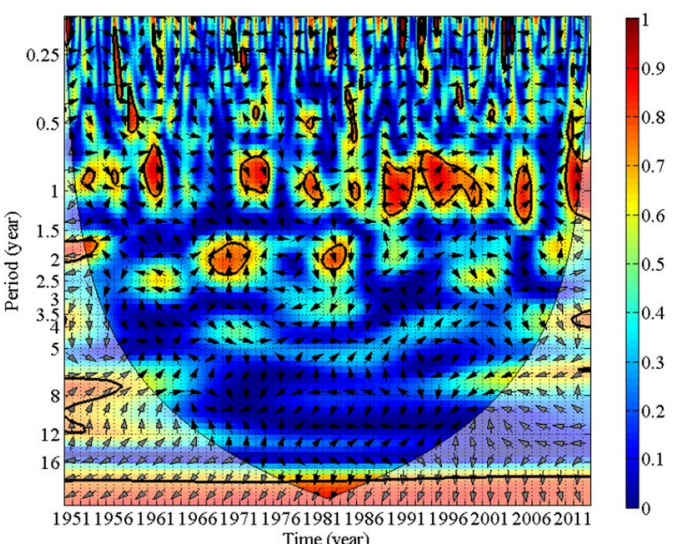

(h)

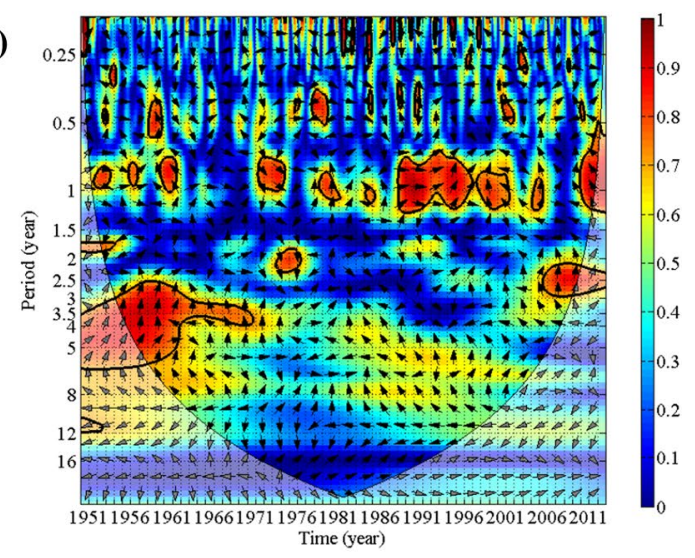

Fig. 6 Wavelet coherence between monthly precipitation and the PDO: a zone I, $\mathbf{b}$ zone II, $\mathbf{c}$ zone III, $\mathbf{d}$ zone IV, e zone V, f zone VI, $\mathbf{g}$ zone VII, and h zone VIII 
precipitation and the PDO on the annual timescale over the entire period of study. The coherence on the annual timescale is slightly higher than that associated with timescales of $<1.0$ year. In addition, the PDO also has considerable influence on both inter-annual and decadal timescales, similar to the ENSO. Again, these influences are also concentrated on certain timescales and during certain years.

\subsection{Global coherence between monthly precipitation and climate indices}

Figure 7 shows the global coherence for all four climate indices in all eight zones, which provides an evaluation of averaged coherence between monthly precipitation and each climate index over different timescales. This analysis is yearly independent, and plotting all indices together enable the comparison of the relative coherence significance of each index in each zone at all timescales.

Strong global coherence with monthly precipitation is observable on the timescale of 1.0 year for both the ISM and the EASM in all eight zones, indicating the dominant effects of monsoons across China. Relatively strong global coherence is also found on 0.5 year timescale for the monsoon indices, particularly for the ISM in Zones I, II, III, IV, VII, and VIII (Fig. 7a-d, g, h). (a)

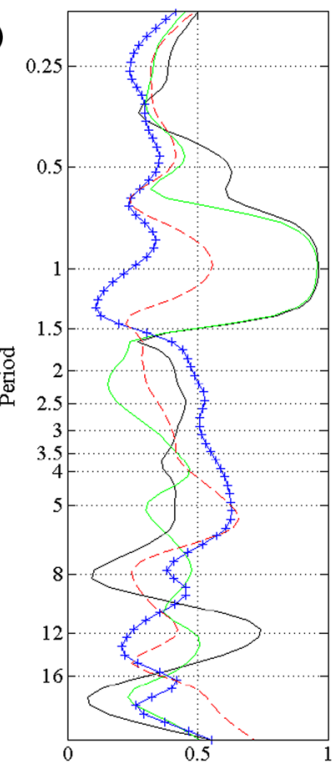

(e)

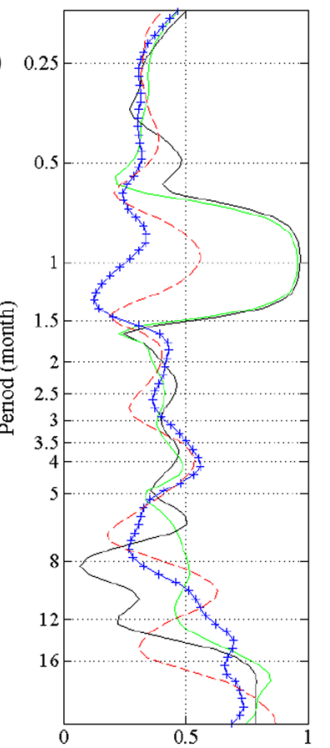

(b)

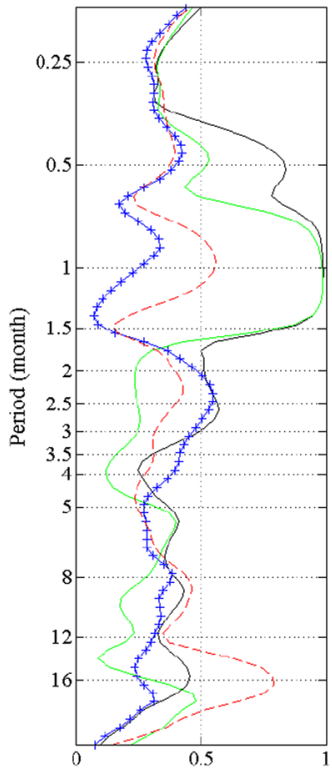

(f)

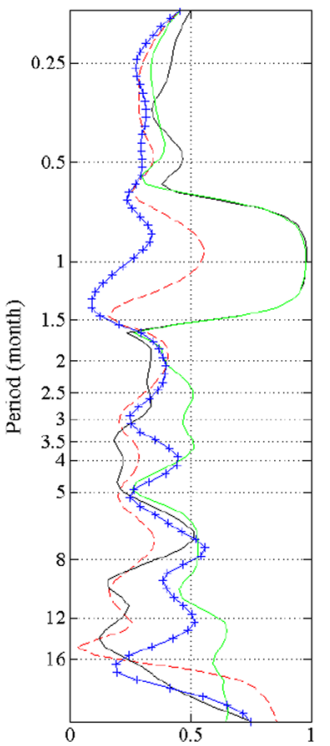

(c)

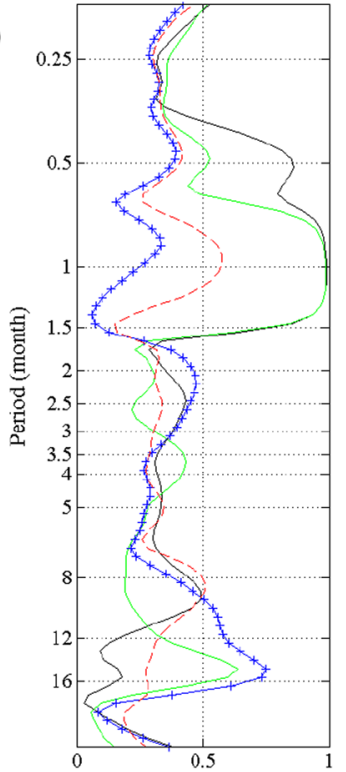

(g)

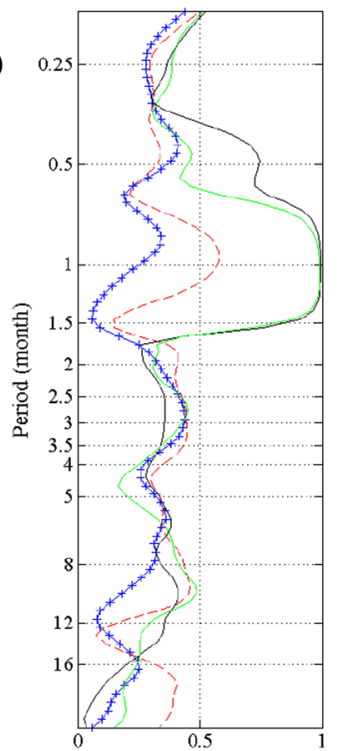

(d)

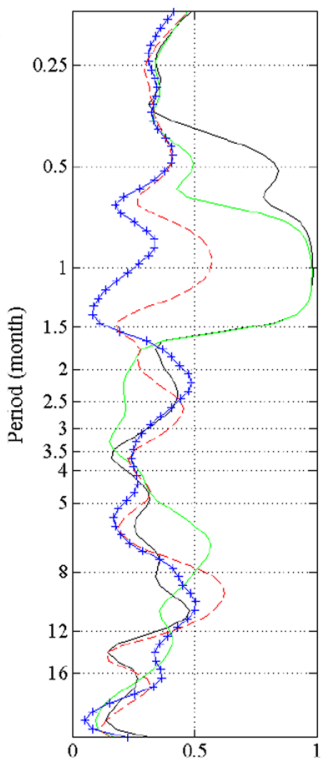

(h)

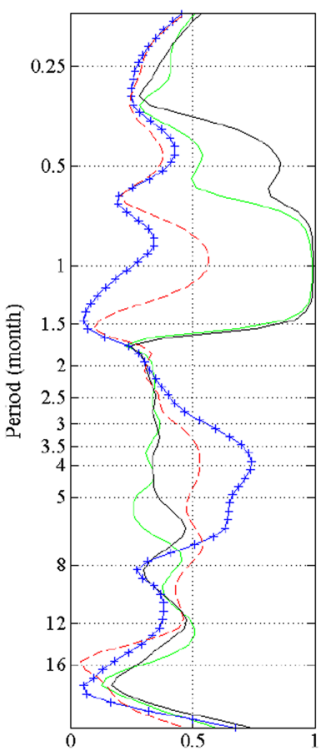

Fig. 7 Global coherence between monthly precipitation and the four climate indices in the eight climate zones: a zone I, b zone II, c zone III, d zone IV, e zone V, f zone VI, g zone VII, and h zone VIII (black: ISM, green: EASM, blue: ENSO, red: PDO) 
On timescales other than annual and intra-annual, the effects of monsoons and teleconnections are more localized (such as the strong ENSO influence on timescales of 12.0-16.0 years in Zone III and on timescales of 3.0-5.0 years in Zone VIII). These localized effects demonstrate the variability of monthly precipitation as the result induced by large-scale climate indices. In some regions, monthly precipitation has similar coherence with all indices (such as in Zone VII on timescales $>2.0$ years). These results demonstrate that the effect of any particular climate index is not significant on large timescales.

\section{Discussions}

\subsection{Monsoons}

It is well known that the Asian summer monsoons (i.e., the ISM and the EASM) dominate the hydrometeorological processes in most Asian regions (Tao and Chen 1987; Huang et al. 1998). Mainland China extends from South Asia to East Asia, which constitutes a large area influenced by the Asian monsoons. Both the ISM and EASM have been found to correlate with climate in China (Zhou and Cheng 1987; Zhou and Jia 2003; Zhang and Pu 2004; Xu and Qian 2006), and the effects of the monsoons vary on different spatiotemporal scales (Liu and Ding 2008b; Ding et al. 2013; Liu and He 2015; Li et al. 2016).

\subsubsection{Correlation between monthly precipitation and the ISM}

The ISM is the strongest monsoon system in the world. Our results show that the ISM has profound correlation with monthly precipitation on various timescales, especially on the annual timescale, across China (Figs. 3, 7).

On intra-annual timescales, the effect of the ISM on monthly precipitation in China varies among the different climate zones; the ISM mainly affects precipitation in Zones II, III, IV, and VIII (Fig. 7b-d, g, h). Areas of high correlation are located in a belt from the Qinghai-Tibet Plateau to Northeastern China, which has been defined as the North Branch of the monsoon by Liu and Ding (2008a). The atmospheric heat source of the Indian low pressure area, together with the Asian summer monsoon trough, enhances the formation of water vapor, and the southwesterly winds in the low latitudes drive the water vapor northeastward. During this process, the Indian low pressure area promotes extension over the Western Pacific ridge, and water vapor from the Western Pacific Subtropical High joins the North Branch of the monsoon (Liu and Ding 2008b). Consequently, the transport of water vapor extends to Northern China (Zone IV) and Northeastern China (Zone III), increasing precipitation from the Qinghai-Tibet Plateau (Zone VIII) to Northeastern China (Zone III) (Guo and Wang 1988; Kripalani and Singh 1993; Zhang et al. 1999, 2016; Liu and Ding 2008a; Ding and Wang 2005).

On annual timescales, the ISM strongly affects monthly precipitation in all eight climate zones (Figs. 3, 7). This agrees with the widely reported influence of the ISM observed across broad and different regions of China (Zhou and Cheng 1987; Kripalani and Singh 1993; Kripalani and Kulkarni 2001; He et al. 2005; Hu et al. 2010; Li et al. 2016; Zhang et al. 2016).

On longer timescales (i.e., decadal and interdecadal), the ISM mainly affects the monthly precipitation in Zones I and V (Figs. 3a, e, 7a, e). The region of Xinjiang (Zone I) is bordered by the Qinghai-Tibet Plateau to the south and by the Iran Plateau to the southwest, which prevent southward transport of water vapor. Xinjiang (Zone I) is known as an arid/semiarid region where overall precipitation is low. However, on the decadal timescale, the Somali jet stream delivers water vapor across the equator and over the Xinjiang (Zone I) area because of the effects of the dipole between the Arabian Sea anticyclone and the Iran cyclone (Yang 2003; Zhou and Jia 2003; Zhang and Deng 1987). This climatic configuration increases the humidity, which affects precipitation in Xinjiang (Zone I) on the decadal timescale. For Zone V, the South Asian High is strongly correlated with the Western Pacific Subtropical High, which influences precipitation in the Yangtze-Huaihe River basin on the timescale of 10-15 years (Zhao et al. 2003; Chen et al. 2011). Precipitation in this basin has distinct variation on the decadal timescale (Zhang and Wu 2001; Qian et al. 2002; Zhang et al. 2002). The influence of the ISM in the middle-lower Yangtze Plain (Zone V) is likely due to the impact of the ISM on the high-altitude atmospheric circulation (Dai et al. 2002). When the ISM strengthens, the 500-hPa geopotential height (contours) increases over East Asia and the Western Pacific Subtropical High extends toward the north and west. Consequently, the westerlies move northward and eastward, bringing large amounts of water vapor from the lower latitudes to the middle-lower Yangtze Plain (Zone V) and promoting precipitation (Liu and Ding 2008c).

\subsubsection{Correlation between monthly precipitation and the EASM}

The EASM system consists of various features including the Australian High, cross-equatorial flow at $105^{\circ} \mathrm{E}$, West North Pacific Subtropical High, Mascarene High, southwest summer monsoon in the South Sea, Intertropical Convergence Zone (ITCZ), and Meiyu front at $30^{\circ} \mathrm{N}$ (Tao and Chen 1987; Huang and Tang 1987). Figures 4 and $7 d-f$ illustrate that the EASM mainly affects precipitation in Zones IV, $\mathrm{V}$, and VI (i.e., eastern China) on inter-annual timescales. Previous 
studies have shown that precipitation in the eastern China is strongly correlated with the Southern Hemisphere circulation (Gao and Wang 2007; Sun et al. 2013). As an important atmospheric circulation feature of the EASM system, the Australian High has significant impact on the climate of eastern China on inter-annual timescales (Huang and Tang 1987; He et al. 1991; Chen et al. 2005; Teng et al. 2005). The Australian High typically strengthens the equatorial westerlies and winds over the ITCZ, prompting the Western Pacific Subtropical High to move southwestward (Zhang et al. 2010). This atmospheric circulation can deliver water vapor to eastern China and produce precipitation. Simultaneously, induced by the effects of the Australian High, the cross-equatorial flow at $105^{\circ} \mathrm{E}$ can become significantly enhanced and enter the South China Sea, strengthening the tropical monsoons. This combined process can increase water vapor transport and contribute to precipitation in eastern China (Chen and Wu 1998).

The most obvious feature of the EASM is its annual scale impact on monthly precipitation in all eight climate zones (Figs. 4, 7). This profound impact has also been reported by Guo (1985), Yu et al. (2009), and Zhang et al. (2011), although these previous studies were limited to specific regions of China.

On decadal and inter-decadal timescales, the results demonstrate that the EASM mainly affects precipitation in Zone I (Xinjiang), Zone V (Yangtze-Huaihe river Plain), and Zone VIII (Qinghai-Tibet Plateau) (Figs. 4, 7). This observation is consistent with the reports in the Yangtze River region by other researchers (Guo 1983; Wang et al. 2001; Lu et al. 2004; Xu et al. 2008; Yu et al. 2009). This decadal-scale correlation is due to the movement of the EASM on the same timescales that affect the precipitation of East China (Lu et al. 2011). The movement usually affects the middle-lower Yangtze Plain from the north (Lu et al. 2011). The Western Pacific Subtropical High moves southwestward, resulting in the appearance of the Meiyu front over the subtropical region of East Asia, which largely affects precipitation in Zone V (Lu et al. 2004; Wang et al. 2001; Zhang and Tao 1998; Chen and Xue 2013). The equatorial westerly winds of the Indian Ocean move eastward through the South China Sea, transporting large volumes of water vapor from the Indochina Peninsula and the South China Sea toward the Yangtze River basin in China, which promotes heavy precipitation in the middle-lower Yangtze Plain (Zhou and Huang 2003; Wang and Kiyotoshi 2005).

On the decadal scale, the EASM also affects precipitation in the Western arid/Semiarid area (Zone I) because of the Mascarene High and the Western Pacific Subtropical High (Wang and Yang 2008; Chen et al. 2012). The Mascarene High causes the trade winds to cross the equator, forming the so-called Somali cross-equatorial flow (Cui et al. 2008). This cross-equatorial flow, which represents the major passage of water vapor between the Southern and Northern hemispheres, primarily affects precipitation in Zone I (Xinjiang) (Li et al. 2010). In addition, when the Western Pacific Subtropical High strengthens and moves southward, it also causes the transport of water vapor from the western North Pacific Ocean to Zone I (Xinjiang). This decadal-scale influence (Figs. 4, 7, and Wang and Xue 2003) is due to the decadal variation of East Asian-Pacific teleconnection ( $\mathrm{Yu}$ et al. 2009; Chen et al. 2012).

A strong EASM reflects a strong atmospheric heat source over the South China Sea and the tropical western Pacific Ocean. If the atmospheric heat source over the Qinghai-Tibet Plateau (Zone VIII) were weak, an atmospheric heat gradient would form (Xu et al. 2016b). As a result, the Western Pacific Subtropical High would be strengthened, which could affect the eastern regions of China (Zhou et al. 2005b). This process would promote the movement of water vapor toward the west, transporting it toward the Qinghai-Tibet Plateau and increasing precipitation in Zone VIII (Zhou et al. 2005a, 2012; Lin et al. 2016).

\subsection{Teleconnections}

\subsubsection{Correlation between monthly precipitation and the ENSO}

The ENSO and the Asian monsoon are interactive (Fu 1985; Xu and Zhu 2005; Zhu et al. 2007; Xu et al. 2016a). Although previous research has shown that the ENSO is one of the major climate indices that affect precipitation in China on inter-annual timescales (Ding 1993), our analyses (Figs. 5, 7a, h) illustrate that, on such timescales, the ENSO mainly affects precipitation in Zones I and VIII, in which Xinjiang and the Qinghai-Tibet Plateau are located, respectively. When La Niña occurs, the Indian High becomes strengthened, which enhances the Somali cross-equatorial flow, causing increased precipitation in Xinjiang in Zone I. Conversely, when El Niño occurs, precipitation in Xinjiang decreases (Chen et al. 2005). In addition, when El Niño occurs, a cyclone appears over the Indian Ocean and the South Asian High strengthens, causing increased precipitation over the Qinghai-Tibet Plateau in Zone VIII (Zhou et al. 2000). The occurrence of La Niña induces the opposite effects in the respective zones.

In the case of El Niño, the sea surface temperature of the tropical eastern Pacific Ocean is high, which results in weakened Walker and Hadley circulations. The enhanced Western Pacific Subtropical High expands southward, which transports water vapor to the Northeastern China (Zone III) and the Northern China (Zone V) regions (Chen 1977; Zou and Ni 1997). This is consistent with our results that indicate that the ENSO has very strong effects on Zones III and V on decadal timescales (Fig. 7), and has relatively strong effects 
on other timescales, although the area of influence in Zone $\mathrm{V}$ is relatively narrow (Fig. 5).

\subsubsection{Correlation between monthly precipitation and the PDO}

Correlation results demonstrated that the PDO mainly affects precipitation in Zone I on inter-annual timescales (Figs. 6, 7a). In the Northern Hemisphere, variations of precipitation and climate are known to be controlled by the EASM and the westerly circulation (An and Chen 2009; Li et al. 2015). Previous discussion has demonstrated the strong effects of the EASM on overall precipitation in China. The effects of the PDO on regional precipitation are mainly attributable to alterations of the intensity of the EASM and the westerly circulation (Gan 2000; Yang et al. 2004; Ma and Shao 2006; Li et al. 2009; He and Jiang 2011).

When the PDO is in its positive phase, the Mascarene High and the Australian High become enhanced and crossequatorial flow strengthens, resulting in increased precipitation in Xinjiang (Zone I) (Wang and Yang 2008). The westerly circulation can also be strengthened by the PDO. Water vapor transported toward Xinjiang by the westerly circulation can enhance precipitation in Zone I because of orographic effects as the air moves over the mountains (Xu et al. 2009).

On decadal or inter-decadal timescales, the PDO mainly affects precipitation in Zones II and VI, which encompass Inner Mongolia and southern areas of China (Figs. 6, 7b, f). The PDO index represents the thermal difference over the North Pacific Ocean, which affects the climate of the Northern Hemisphere with decadal-scale periodicity (Hurrell and van Loon 1997).

The water vapor associated with precipitation over Inner Mongolia (East arid, Zone II) in summer is derived mainly from the South China Sea and the Bay of Bengal (Wu et al. 2012). When the PDO is in its positive phase, both the westerly jet and the Western Pacific Subtropical High move northward; thus, Inner Mongolia becomes influenced by the westerly circulation. There are no mountains in central eastern parts of Inner Mongolia. This means large quantities of water vapor from the Bay of Bengal, South China Sea, and western Pacific Ocean can be transported to the Hetao belt and Inner Mongolia (East arid, Zone II), promoting local precipitation (Qu et al. 2004; Xu et al. 2009; Li et al. 2011).

When the PDO is in its positive phase, sea surface temperature in the middle of the North Pacific Ocean is low and the Aleutian Low is weak, which causes high pressure over Northeast Japan and low pressure over the Qinghai-Tibet Plateau. This synoptic situation results in an area of vertical ascent over Southern China (Zone VI), which is advantageous to water vapor convergence and increased precipitation. At the same time, the sea surface temperature of the equatorial Pacific Ocean will become colder, which leads to an anticyclone over the Philippines and water vapor transport from the South China Sea to Southern China (Zone VI) (Cheng et al. 2016). Moreover, when a positive PDO phase is combined with El Nino, an anticyclonic circulation will develop in the northwestern Pacific Ocean. Associated southerly winds will enhance the southwesterly warm wet flow, increasing the transport of water vapor toward southern China. Meanwhile, the Western Pacific Subtropical High will become strengthened and move westward. This also acts to enhance the southwesterly airflow and the transport of water vapor from the South China Sea toward South China (Zone VI) (Li et al. 2010; Gu 2008).

\section{Conclusions}

To obtain better understanding of the effects of large-scale climatic phenomena on precipitation across eight climate zones of China, this study applied wavelet coherence and global coherence in the acquisition of correlations between monthly precipitation and both monsoons (the ISM and the EASM) and teleconnections (the ENSO and the PDO) on different timescales. This work illustrated new results on the timescale of the influences of these climate indices on the precipitation in different regions of China, which is important for both management of water resources and the prediction of precipitation with consideration of future climate change across China.

The major conclusions derived are outlined in the following.

1. On the annual timescale, monsoons have stronger effects than teleconnections on monthly precipitation in all eight climate zones of China.

2. On the intra-annual (0.5-1 year) and inter-annual (2-10 year) scales, the ISM mainly affects precipitation in the East Arid Region, Northeastern China, Northern China, and Qinghai-Tibet Plateau; the EASM mainly affects Northern China, Central China, and Southern China; the ENSO mainly affects Western Arid/Semiarid region and Qinghai-Tibet Plateau; the PDO mainly affects the Western Arid/Semiarid region.

3. On the decadal timescale, the ISM mainly affects the Western arid/Semiarid and Central China; the EASM mainly affects Western arid/Semiarid, Central China, and Qinghai-Tibet Plateau; the ENSO mainly affects Northeastern China and Central China; and the PDO mainly affects East arid and Southern China regions.

Acknowledgements This work is partially supported by National Natural Science Foundation of China (41272245, 40972165 and 40572150), 
and Natural Science Foundation of Tianjin, China (18JCZDJC39500). The authors sincerely thank two anonymous reviewers for their detailed and constructive comments to improve this manuscript.

\section{Compliance with ethical standards}

Conflict of interest The authors declare that they have no conflict of interest.

Open Access This article is distributed under the terms of the Creative Commons Attribution 4.0 International License (http://creativeco mmons.org/licenses/by/4.0/), which permits unrestricted use, distribution, and reproduction in any medium, provided you give appropriate credit to the original author(s) and the source, provide a link to the Creative Commons license, and indicate if changes were made.

\section{References}

An CB, Chen FH (2009) The pattern of Holocene climate change in the arid central Asia: a case study based on lakes. J Lake Sci 21(3):329-334 (in Chinese)

Chan JCL, Zhou W (2005) PDO, ENSO and the early summer monsoon rainfall over south China. Geophys Res Lett 32:L08810. https://doi.org/10.1029/2004GL022015

Chen H, Xue F (2013) Numerical simulation of the decadal variations in the East Asian summer monsoon and summer rainfall in eastern China. Chin J Atmos Sci 37(5):1143-1153. https://doi. org/10.3878/j.issn.1006-9895.2012.12130 (in Chinese)

Chen B, Guo PW, Xiang YC (2005) Relationship between summer cross-equatorial flows and ENSO. J Nanjing Inst Meteorol 28(1):36-43 (in Chinese)

Chen YR, Li YQ, Qi DM (2011) Variations of South Asia High and West Pacific Subtropical High and their relationships with precipitation. Plateau Meteorol 30(5):1148-1157 (in Chinese)

Chen YL, Zhao YP, Feng JQ, Wang F (2012) ENSO cycle and climate anomaly in China. Chin J Oceanol Limn 30(6):985-1000. https ://doi.org/10.1007/s00343-012-1245-1

Cheng C, Zhu YM, Yu B et al (2016) Interdecadal shift of March precipitation and atmospheric circulation in South China and their relationships with PDO. J Arid Meteorol 34(6):936-944. https:// doi.org/10.11755/j.issn. 1006-7639(2016)-06-0936 (in Chinese)

Chiew FHS, Piechota TC, Dracup JA, McMahon TA (1998) El Nino/Southern Oscillation and Australian rainfall, streamflow and drought: links and potential for forecasting. J Hydrol 204(1-4):138-149

Christensen JH, Kanikicharla KK, Marshall G, Turner J (2013) Climate phenomena and their relevance for future regional climate change. Cambridge University Press, Cambridge, pp 1-92

Cui J, Yang XQ, Zhang AZ (2008) Characteristics of mascarene high variation. Meteor Sci Tech 36(1):35-42 (in Chinese)

Dai XG, Chou JF, Wu GX (2002) The teleconnection relationship between Indian monsoon and East Asian Summer circulation. Acta Meteorol Sin 60(5):544-552 (in Chinese)

Ding YH (1993) Monsoons over china [M]. Kluwer Academic Publishers, Dordrecht

Ding QH, Wang B (2005) Circumglobal teleconnection in the Northern Hemisphere summer. J Clim 18(17):3483-3505. https://doi. org/10.1175/JCLI3473.1

Ding YH, Sun Y, Liu YY (2013) Interdecadal and interannual variabilities of the Asian summer monsoon and its projection of future change. J Atmos Sci 37(2):253-280 (in Chinese)
Fleming SW, Quilty EJ (2006) Aquifer responses to El Niño-Southern Oscillation. Southwest Br Columbia Groundw 44(4):595-599

Fu CB (1985) Interannual summer monsoon variability in China associated with E1 Niño/Southern Oscillation. In: Proceedings of international conference on monsoon in far east, Tokyo, 264-270

Gadgil S, Sajani S (1998) Monsoon precipitation in the AMIP runs. Clim Dyn 14(9):659-689. https://doi.org/10.1007/s003820050 248

Gan TY (2000) Reducing vulnerability of water resources of Canadian prairies to potential droughts and possible climatic warming. Water Resour Manag 14(2):111-135

Gao H, Wang YG (2007) On the weakening relationship between summer precipitation in China and ENSO. Acta Meteorol Sin 65(1):131-136

Grinsted A, Moore JC, Jevrejeva S (2004) Application of the cross wavelet transform and wavelet coherence to geophysical time series. Nonlinear Proc Geophys 11:561-566

$\mathrm{Gu}$ W (2008) Interdecadal variabilities of the summer precipitation over East China and its mechanism. PhD dissertation. Graduate University of Chinese Academy of Sciences (in Chinese)

Guo QY (1983) The summer monsoon intensity index in East Asia and its variation. Acta Geogr Sin 38(3):207-216 (in Chinese)

Guo QY (1985) The variations of summer monsoon in East Asia and the rainfall over China. J Trop Meteorol 1(1):44-52 (in Chinese)

Guo QY, Wang JQ (1988) A comparative study on summer monsoon in China and India. J Trop Meteorol 4(1):53-60 (in Chinese)

Hamada JI, Yamanaka MD, Matsumoto J, Fukao S, Winarso PA, Sribimawati T (2002) Spatial and temporal variations of the rainy season over Indonesia and their link to ENSO. J Meteorol Soc Jpn 80(2):285-310. https://doi.org/10.2151/jmsj.80.285

Hao YH, Zhang J, Wang JJ, Li RF, Hao PM, Zhan HB (2016) How does the anthropogenic activity affect the spring discharge? J Hydrol 540:1053-1065

He PC, Jiang J (2011) Effect of PDO on the relationships between large-scale circulation and tropical cyclone activity over the western North Pacific. J Atmos Sci 31(3):266-273 (in Chinese)

He JH, Li J, Li YP (1991) Numerical experiment with processes for effect of Australian cold air activity on East-Asian Summer Monsoon. Acta Meteorol Sin (1):51-59

He LF, Wu BY, Mao WX (2005) The interdecadal variability of Indian summer monsoon and the climate state shift in North China. J Trop Meteorol 21(3):257-264 (in Chinese)

Hu JG, Tao L, Zhou B (2010) Characteristic of South Asia High activity and its relation with the precipitation of East China in summer. Plateau Meteorol 29(1):128-136 (in Chinese)

Huang TS, Tang MM (1987) On the structure of the summer monsoon regime of East Asia. Acta Meteorol Sin 13(3):1-14 (in Chinese)

Huang RH, Zhang ZZ, Huang G, Ren BH (1998) Characteristics of the water vapor transport in East Asian monsoon region and its difference from that in South Asian monsoon region in summer. Chin J Atmos Sci 22(4):460-469 (in Chinese)

Hurrell JW, van Loon H (1997) Decadal variations in climate associated with the North Atlantic Oscillation. Clim Change 36(3-4):301-326

Karl TR, Nicholls N, Ghazi A (1999) CLIVAR/GCOS/WMO workshop on indices and indicators for climate extremes-workshop summary. Clim Change 42:3-7

Kripalani RH, Kulkarni A (2001) Monsoon rainfall variations and teleconnections over South and East Asia. Int J Climatol 21(5):603616. https://doi.org/10.1002/joc.625

Kripalani RH, Singh SV (1993) Large-scale aspects of India-China summer monsoon rainfall. Adv Atmos Sci 10(1):71-84

Labat D (2010) Cross wavelet analyses of annual continental freshwater discharge and selected climate indices. J Hydrol 385(1-4):269278. https://doi.org/10.1016/j.jhydrol.2010.02.029 
Lau KM, Li MT (1984) The monsoon of East Asia and its global association-a survey. Bull Amer Meteorol Soc 65:114-125

Li HJ, Jiang ZH, Yang Q (2009) Association of North Atlantic Oscillations with Aksu River runoff in China. J Geogr Sci 19(12):12-24. https://doi.org/10.1007/s11442-009-0012-5

Li HY, Lin ZH, Chen H (2010) Interdecadal variability of precipitation in March over South China. Climatic Environ Res 15(3):311-321 (in Chinese)

Li CY, Wang LQ, Gu W (2011) Interannual time-scale relationship between Mongolia High and SST anomaly in the North Pacific in winter. Chin J Atmos Sci 35(2):193-200 (in Chinese)

Li WB, Li CY, Liu ZJ et al (2015) Distribution of precipitation and its effect factors analysis in the central and western regions of Inner Mongolia during the last 60 years. J IM Agric Univ (Natural Science Edition) 36(1):85-94 (in Chinese)

Li DL, Zhang Q, Yao HR, Yao HR, Li X (2016) Relationships between North Indian summer monsoon and midsummer rainfall in Hetao and its vicinity regions of China. Plateau Meteorol 35(6):15121523. https://doi.org/10.7522/j.issn.1000-0534.2016.00075 (in Chinese)

Liu YY, Ding YH (2008a) A study of the teleconnection in the AsianPacific monsoon region. Acta Meteorol Sin 66(5):670-682

Liu YY, Ding YH (2008b) Analysis and numerical simulation of the teleconnection between Indian summer monsoon and precipitation in North China. Acta Meteorol Sin 66:789-799

Liu YY, Ding YH (2008c) Teleconnection between the Indian summer monsoon onset and the Meiyu over the Yangtze River Valley. Sci China Ser D-Earth Sci 51(7):1021-1035

Liu BQ, He JH (2015) Reviews on the dynamics of Asian summer monsoon. J Trop Meteorol 31(6):869-880 (in Chinese)

Lu JM, Ren JZ, Ju JH (2004) The interdecadal variability of East Asia monsoon and its effect on the rainfall over China. J Trop Meteorol 10(1):14-22

Lu XY, Zhang XZ, Chen JN (2011) The interdecadal variability of North-South movement of East Asian Summer monsoon and its effect on the regional rainfall over China. J Trop Meteorol 27(6):860-868. https://doi.org/10.3969/j.issn.10044965.2011.06.009 (in Chinese)

Ma ZG, Shao LJ (2006) Relationship between dry/wet variation and the Pacific decadal oscillation (PDO) in northern China during the last 100 years. Chin J Atmos Sci 30(3):464-474 (in Chinese)

Partal T, Kucuk M (2006) Long-term trend analysis using discrete wavelet components of annual precipitation measurements in Marmara region (Turkey). Phys Chem Earth 31(18):1189-1200

Peng SL, Mysak LA (1993) A teleconnection study of interannual sea surface temperature fluctuations in the northern North Atlantic and precipitation and runoff over Western Siberia. J Clim 6(5):876-885

Qian YF, Zhang Q, Yao YH, Zhang XH (2002) Seasonal variation and heat preference of the South Asia High. Adv Atmos Sci 19(5):821-836

Qu WJ, Zhang XY, Wang D et al (2004) The important significance of westerly wind study. Mar Geol Quat Geol 24(1):125-132 (in Chinese)

Sun D, Xue F, Zhou TJ (2013) The influence of the Southern Hemisphere circulation on summer rainfall in China under the different decadal background. Clim Environ Res 18(1):51-62. https://doi. org/10.3878/j.issn.1006-9585.2012.11007 (in Chinese)

Sun QH, Miao CY, Duan QY (2017) Changes in the spatial heterogeneity and annual distribution of observed precipitation across China. J Clim 30:9399-9416. https://doi.org/10.1175/ JCLI-D-17-0045.1

Tao SY, Chen LX (1987) A review of recent research on the East Asian summer monsoon in China. In: Chang CP, Krishnamurti TN (eds) Monsoon meteorology. Oxford University Press, New York, pp 60-92
Teng DG, Liu XF, Zhang ZX, Wu SA (2005) Interannual variation of Australian High and its effect on Asia-Australia Monsoon circulation system in summer. J Nanjing Inst Meteorol 28(1):86-92 (in Chinese)

Torrence C, Compo GP (1998) A practical guide to wavelet analysis. Bull Am Meteorol Soc 79(1):61-78

Torrence C, Webster PJ (1999) Interdecadal changes in the ENSOmonsoon system. J Clim 12(8):2679-2710

Tremblay A, Larocque M, Anctil F, Rivard C (2011) Teleconnections and interannual variability in Canadian groundwater levels. J Hydrol 410:178-188. https://doi.org/10.1016/j.jhydr ol.2011.09.013

Trenberth KE, Stepaniak DP, Caron JM (2000) The global monsoon as seen through the divergent atmospheric circulation. J Clim 13:3969-3993

Wang YF, Kiyotoshi T (2005) Decadal Climate variability of rainfall around the middle and lower reaches of Yangtze River and atmospheric circulation. J Trop Meteorol 11(2):169-177

Wang HJ, Xue F (2003) Interannual variability of Somali jet and its influences on the inter-hemispheric water vapor transport and on the East Asian summer rainfall. Chinese J Geophys 46(1):1825. (in Chinese)

Wang WP, Yang XQ (2008) Variation of Somali jet and its impact on East Asian summer monsoon and associated China rainfall anomalies. Sci Meteorol Sin 28(2):139-146 (in Chinese)

Wang B, Wu R, Lau KM (2001) Interannual variability of the Asian summer monsoon: Contrasts between the Indian and the Western North Pacific-East Asian monsoons. J Clim 14:4073-4090

Webster PJ, Magaña VO, Palmer TN, Shukla J, Tomas RA, Yanai M, Yasunari T (1998) Monsoons: processes, predictability and the prospects for prediction. J Geophys Res 103:14451-14510

Winograd IJ, Riggs AC, Coplen TB (1998) The relative contributions of summer and cool-season precipitation to groundwater recharge, Spring Mountains, Nevada, USA. Hydrogeol J 6(1):77-93. https://doi.org/10.1007/s100400050135

Wu JK, Ding YJ, Ye BS, Yang QY, Hou DJ, Xue LY (2012) Stable Isotopes in Precipitation in Xilin River Basin, Northern China and their implications. Chin Geogra Sci 22(5):531-540. https ://doi.org/10.1007/s11769-012-0543-Z

Xiao MZ, Zhang Q, Singh VP, Chen XH (2013) Regionalizationbased spatiotemporal variations of precipitation regimes across China. Theor Appl Climatol 114(1-2):203-212. https://doi. org/10.1007/s00704-013-0832-1

Xiao MZ, Zhang Q, Singh VP (2015) Influences of ENSO, NAO, IOD and PDO on seasonal precipitation regimes in the Yangtze River Basin, China. Int J Climatol 35:2556-3567. https://doi. org/10.1002/joc.4228

Xu ZF, Qian YF (2006) Moist potential vorticity index of Indian monsoon and its relationship with climate in China. Acta Meteorol Sin 64(6):760-769 (in Chinese)

$\mathrm{Xu} \mathrm{JJ}$, Zhu QG (2005) The numerical simulation of the responding of Indian and East-Asian Summer Monsoon circulation to ENSO and interdecadal variation. J Atmos Sci 23(2):214-226 (in Chinese)

Xu XD, Lu CG, Shi XH et al (2008) World water tower: an atmospheric perspective. Geophys Res Lett 35(20):L20815. https:// doi.org/10.1029/2008GL035867

Xu LG, Zhou HF, Liang C, Wu AQ (2009) Multi-time scale variability of precipitation in the desert region of North China. $\mathrm{J}$ Hydraul Eng 40(8):1002-1011 (in Chinese)

Xu ZQ, Fan K, Wang HJ (2015) Decadal variation of summer precipitation over China and associated atmospheric circulation after the late 1990s. J Clim 28:4086-4106. https://doi.org/10.1175/ JCLI-D-14-00464.1

Xu PQ, Feng J, Chen W (2016a) Asymmetric roles of ENSO in the link between the East Asian winter monsoon and the following 
summer monsoon. J Atmos Sci 40(4):831-840. https://doi. org/10.3878/j.issn.1006-9895.1509.15192 (in Chinese)

Xu TT, Fan GZ, Lai X, Zhang YL (2016b) The thermal contrast over the Tibetan Plateau, the East Asian and the Pacific Ocean in strong and weak East Asia monsoon years. J Chengdu Univ Info Tech 31(6):600-606 (in Chinese)

Yang LM (2003) Research on a case of heavy rain in Xinjiang from South Asia High abnormity. Meteorol Mon 29(8):21-25 (in Chinese)

Yang HJ, Zhang Q (2003) On the decadal and interdecadal variability in the Pacific Ocean. Adv Atmos Sci 20(2):173-184

Yang XQ, Zhu YM, Xie Q, Ren XJ, Xu GY (2004) Advances in studies of Pacific Decadal Oscillation. Chin J Atmos Sci 28(6):979-992 (in Chinese)

Yu SQ, Shi XH, Lin XC (2009) Interannual variation of East Asian summer monsoon and its impacts on general circulation and precipitation. J Geogr Sci 19:67-80. https://doi.org/10.1007/s1144 2-009-0067-3

Zhang JB, Deng ZF (1987) A generality of precipitation in Xinjiang. China Meteorological Press, Beijing (in Chinese)

Zhang J, Lin Z (1985) Climate in China. Shanghai Scientific and Technical Publishers, Shanghai (in Chinese)

Zhang TF, Pu GM (2004) Analysis of 6 Yunnan severe rainfalls affected by Indian monsoon in June 2002. Acta Meteorol Sin 24(3):325-332 (in Chinese)

Zhang QY, Tao SY (1998) Summer East Asian tropical and subtropical monsoon and rainfall in eastern China. J Appl Meteorol Sci 9(suppl.):16-23 (in Chinese)

Zhang Q, Wu GX (2001) The large area flood and drought over Yangtze River Valley and its relation to the South Asia High. Acta Meteorol Sin 59(5):569-577 (in Chinese)

Zhang RH, Sumi A, Kimoto M (1999) A diagnostic study of the impact of El Nino on the precipitation in China. Adv Atmos Sci 16(2):229-241

Zhang Q, Wu GX, Qian YF (2002) The bimodality of $100 \mathrm{hPa}$ South Asia High and its relationship to the climate anomaly over East Asia in summer. J Meteorol Soc Jpn 80(4):733-744. https://doi. org/10.2151/jmsj.80.733

Zhang PB, Guan ZY, Sun MN, Cao SY (2010) Possible impacts of the interannual variability of the Australian High on summertime rainfall in China as revealed by the SVD analysis. Acta Meteorol Sin 68(6):908-917 (in Chinese)

Zhang HG, Li ZC, Song Y, Wu YL, Wang XL (2011) Spatial patterns of change trend in rainfall of China and the role East Asia summer monsoon. Arid Land Geog 34(1):34-42 (in Chinese)
Zhang WX, Zhang LX, Zhou TJ (2016) Interannual variability and the underlying mechanism of summer precipitation over the Yarlung Zangbo River basin. J Atmos Sci 40(5):965-980. https://doi. org/10.3878/j.issn.1006-9895.1512.15205 (in Chinese)

Zhao BK, Yao XP, Wu GX (2005) The structure and activity characteristics of the western Pacific subtropical anticyclone and its dynamical mechanism during the Meiyu period over the Huaihe River Basin in 2003. J Atmos Sci 29(5):771-779 (in Chinese)

Zhou JY, Cheng QY (1987) The relationship between Indian monsoon system in summer and the continuous heavy rain over upper reaches of the Changjiang. Acta Meteorol Sin 2(3):360-370

Zhou LT, Huang RH (2003) Research on the characteristics of interdecadal variability of summer climate in China and its possible cause. Clim Environ Res 8(3):274-290 (in Chinese)

Zhou SW, Jia L (2003) Interannual variation of Indian Monsoon and summer flood/drought over Tibetan Plateau. Plateau Meteorol 22(4):410-415. https://doi.org/10.3321/j.issn:10000534.2003.04.016 (in Chinese)

Zhou LT, Wu R (2010) Respective impacts of the East Asian winter monsoon and ENSO on winter rainfall in China. J Geophys Res 115:D02107. https://doi.org/10.1029/2009JD012502

Zhou SW, Jia L, Du J (2000) ENSO influence on the Indian summer monsoon and precipitation on the Tibetan Plateau. Sitsang Sci Tech 90(3):68-73 (in Chinese)

Zhou CY, He JH, Li W (2005a) Climatological characteristics of water vapor transfer over East Asia in summer. J Nanjing Inst Meteorol 28(1):18-27 (in Chinese)

Zhou CY, Li YQ, Li W, Chen LX (2005b) Climatological characteristics of water vapor transport over eastern part of Qinghai-Xizang Plateau and its surroundings. Plateau Meteorol 24(6):880-888 (in Chinese)

Zhou CY, Tang XY, Li YQ (2012) Overview of the research on the water vapor and water vapor transport over the Tibetan Plateau and its surroundings. Plateau Mt Meteorol Res 32(3):76-82. https ://doi.org/10.3969/j.issn.1674-2184\&\%23x00B7;2012.03.017 (in Chinese)

Zhu YM, Yang XQ, Chen XY, Zhao SS, Sun XG (2007) Interdecadal variation of the relationship between ENSO and summer interannual climate variability in China. J Trop Meteorol 13(2):132-136

Zou L, Ni YQ (1997) Impact of ENSO on the variability of the summer monsoon over Asia and the summer rainfall in China. J Trop Meteor 13(4):306-314 (in Chinese) 